\title{
1 Antimony and arsenic biogeochemistry in the East China Sea
}

2 Jing-Ling Ren ${ }^{1,2}$, Xu-Zhou Zhang ${ }^{1,2}$, You-Xu Sun ${ }^{1,2}$, Su-Mei Liu ${ }^{1,2}$, Daji Huang ${ }^{3,4}$, Jing Zhang ${ }^{5}$

3

$4 \quad{ }^{1}$ Key Laboratory of Marine Chemistry Theory and Technology, Ministry of Education, Ocean

5 University of China, Qingdao 266100, China;

$6 \quad{ }^{2}$ Qingdao Collaborative Innovation Center of Marine Science and Technology, Qingdao

$7 \quad 266100$, China;

$8 \quad{ }^{3}$ State Key Laboratory of Satellite Ocean Environment Dynamics, Second Institute of

9 Oceanography, State Oceanic Administration, Hangzhou 310012, China;

$10{ }^{4}$ Ocean College, Zhejiang University, Hangzhou, 310058, China;

$11{ }^{5}$ State Key Laboratory of Estuarine and Coastal Research, East China Normal University,

12 Shanghai 200062, China

13

$14 *$ Corresponding author: Tel +86-532-66782005

15

16
Fax +86-532-66781810

E-mail renjingl@ouc.edu.cn 
Abstract: The biogeochemical cycles of the metalloid elements arsenic and antimony in the East China Sea (ECS), one of the most important marginal seas for western Pacific, were examined in May 2011. Dissolved inorganic arsenic $(\mathrm{As}(\mathrm{V})$ and $\mathrm{As}(\mathrm{III}))$ and antimony $(\mathrm{Sb}(\mathrm{V})$ and $\mathrm{Sb}(\mathrm{III}))$ species were determined by selective hydride generation-atomic fluorescence spectrometry (HG-AFS). Results show that total dissolved inorganic arsenic (TDIAs; [TDIAs] $=[\mathrm{As}(\mathrm{V})]+[\mathrm{As}(\mathrm{III})])$ were moderately depleted in the surface water and enriched in the deep water. Arsenite (As(III)) showed different vertical profiles with that of TDIAs, with significant surface enrichment in the middle shelf region where the concentrations of phosphate were extremely low. Speciation of dissolved arsenic was subtly controlled by the stoichiometric molar ratio of arsenate $(\mathrm{As}(\mathrm{V}))$ to phosphate. The average As(V)/P ratio for the ECS in spring 2011 was $10.8 \times 10^{-3}$, which is higher than previous results and indicates the arsenate stress. The concentrations of total dissolved inorganic antimony (TDISb; [TDISb] $=[\mathrm{Sb}(\mathrm{V})]+[\mathrm{Sb}(\mathrm{III})])$ were high near the Changjiang Estuary and the coastal area of Hangzhou Bay and decreased moderately off the coast. TDISb displayed moderate conservative behavior in the ECS that confirms by the correlations with salinity and dissolved aluminum. Different with that of $\mathrm{As}(\mathrm{III})$, antimonite (Sb(III)) concentrations were extremely lower in the ECS, with relative higher concentration appeared at the bottom layer which indicates the contribution from sediment-water interface. A preliminary box model was established to estimate the water-mass balance and antimony budgets for the ECS. Compared with other areas in the world, the concentrations of dissolved inorganic arsenic and antimony in the ECS remain at natural levels.

Keywords: arsenic; antimony; speciation; biogeochemistry; East China Sea 


\section{Introduction:}

The East China Sea (ECS) is one of the largest marginal seas in the western Pacific Ocean, characterized by the seasonal variability of monsoons and interacting with large rivers (e.g. Changjiang) and Kuroshio in their western and eastern boundaries, respectively (Zhang and Su, 2004). The Changjiang (Yangtze River) contributes nearly $90 \%$ of the whole river discharges into the Yellow Sea and East China Sea (Zhang et al., 2007), with annual water and sediment discharges of about $928.2 \times 10^{9} \mathrm{~m}^{3} \mathrm{yr}^{-1}$ and $0.49 \times 10^{9}$ tons $\mathrm{yr}^{-1}$ (decreased to $0.154 \times 10^{9}$ tons $\mathrm{yr}^{-1}$ at Datong gauging station during 2003-2008 due to the impoundment of Three Gorges Dam at Yichang (Milliman and Meade, 1983; Li et al., 2011; Wang et al., 2011)), of which 70\% is in the wet season (May-October) (Chen et al., 2008). The Changjiang Diluted Water (CDW) extends northeastward to the vicinity of Cheju Island in summer, while hugs the Chinese coast southwestward within a narrow band in winter (Chang and Isobe, 2003). The main currents flowing into and out of the ECS are the Kuroshio Current (KUC) flowing along the shelf break, the Taiwan Strait Warm Water (TSWW) entering through the Taiwan Strait, and the Tsushima Current (TSC) exiting through the Tsushima Strait (Su and Pan, 1987; Teague et al., 2005; Guo et al., 2006).

As members of Group 5 in the Periodic Table of Chemical Elements, trace elements arsenic (As) and antimony $(\mathrm{Sb})$ might have similar chemical properties with that of phosphate. Both $\mathrm{As}$ and $\mathrm{Sb}$ occur in several oxidation states $(+5,+3,0,-3)$, in which the pentavalent arsenate $\left(\mathrm{AsO}_{4}{ }^{3-}\right)$ and antimonate $\left(\mathrm{SbO}_{4}{ }^{3-}\right)$ are the predominantly forms existed in most oxygenated surface waters. The biogeochemical cycling of As and $\mathrm{Sb}$ is complicated by the existence of multiple chemical species, diverse sources, selective uptake and different toxicities (Andreae, 1979; Cutter and Cutter, 1995). 
1 The sources of metalloid elements in the natural waters are from riverine input, from upwelling of

2 subsurface waters and also from atmospheric deposition. Anthropogenic emissions of $\mathrm{Sb}$ and As to

3 the atmosphere have exceeded the natural sources (Cutter and Cutter, 1995; Nriagu, 1989). The

4 enrichment factors (relative to the element/Sc ratios of typical crust rocks) for Sb and As are 70

5 and 20, respectively (Shotyk et al., 1996; Filella et al., 2002).

6 Most studies of As biogeochemistry in the ocean have demonstrated that dissolved As shows

7 nutrient-like profile like phosphate (minor surface depletion and deep-water enrichment), with

8 concentrations ranging from 14 to $25 \mathrm{nM}$ (Andreae, 1979; Middelburg et al., 1998; Cutter and

9 Cutter, 1998; Cutter et al., 2001; Cutter and Cutter, 2006). Despite the thermodynamic instability

in the presence of oxygen, arsenite (As(III)) is also found in natural waters at the nanomolar level,

11 which is believed to be due to the presence of a reducing environment, biologically mediated by phytoplankton production, bacterial dissimilatory reduction, or photochemical generation (Neff, 1997; Oremland et al., 2000; Oremland and Stolz, 2003). Recently, arsenite has been suggested as a chemical proxy of phosphate limitation in combination of alkaline phosphate activity (APA) (Wurl et al., 2013). More and more results have shown that phytoplankton could uptake arsenate and release arsenite or methyl arsenic as a function of phosphate concentration, due to the similarity of chemical properties between arsenate and phosphate (Sanders et al., 1994; Cutter et al., 2001; Hellweger et al., 2003; Cutter and Cutter, 2006; Ren et al., 2010). Additionally, methylated arsenicals (e.g., monomethylarsenic (MMA), dimethylarsenic (DMA)) can be produced through phytoplankton detoxification, microbial action, or bioaccumulation and release, which are dominant over other organoarsenicals (Andreae and Klumpp, 1979; Sanders and Riedel, 
As in natural waters (Andreae, 1979; Cutter et al., 2001).

The oceanographic distributions of dissolved Sb have far less been reported compared to As.

The oceanic behavior of $\mathrm{Sb}$ is quite different with that of As, showing either conservative behavior

4 or mildly scavenged vertical profile in the open ocean (Middelburg et al., 1998; Cutter and Cutter,

5 1995, 1998; Cutter et al., 2001). Antimonite (Sb(III)) and methylated antimony (primarily

monomethyl (MMSb)) are also detected in surface waters (Ellwood and Maher, 2002). However,

7 there are no results to support that Sb show a similar detoxification pathway like As. The sources

8 of reduced and methylated $\mathrm{Sb}$ are still remained unidentified.

9 China holds large reserves of As and $\mathrm{Sb}$ ores and is also one of large producing countries in the world (Carlin, 2000; Xiao et al., 2008). China produced $1.5 \times 10^{5}$ tons $\mathrm{yr}^{-1}$ of Sb in 2012, which

11 contributed more than $80 \%$ of world mine production (Carlin, 2000; Filella et al., 2002; Wang et al., 2014). The drainage basin of the Changjiang has abundant mineral resources of As and Sb. The concentrations of $\mathrm{Sb}$ in rivers around the world's largest $\mathrm{Sb}$ mine of Xikuangsha (Hunan Province,

14 China) ranged from $6 \mu \mathrm{g} / \mathrm{l}$ to $6384 \mu \mathrm{g} / \mathrm{l}$ for waters and from $57 \mathrm{mg} / \mathrm{kg}$ to $7316 \mathrm{mg} / \mathrm{kg}$ for sediments, which revealed the serious contamination compared to the average Sb concentrations in world rivers $(1 \mu \mathrm{g} / \mathrm{l})$ and soils ( $1 \mathrm{mg} / \mathrm{kg})$ (He and Wan, 2004; Wang et al., 2011). The impact of anthropogenic activities (e.g. mining and agricultural use (herbicides, pesticides, and fungicides)) on the ECS and the north western Pacific Ocean are needed to be investigated. For our knowledge, there are some results of dissolved arsenic in the major rivers and marginal seas of China (Huang et al., 1998; Yao et al., 2006, 2007; Duan et al., 2010; Ren et al., 2010; Li et al., 2014). However, there are few works about the biogeochemical behavior of antinomy in the ECS (Zhang et al., 
1 ECS in spring of 2011, attempts to elucidate the influence of chemical, hydrographic and

2 biochemical processes on their distribution, and to understand the As and Sb dynamics with

3 sustainability of ecosystems.

\section{Materials and Methods}

\subsection{Station locations and sampling}

The field observation was carried out in the southern part of Yellow Sea (YS) and ECS aboard the $R / V$ "Shi Yan 3" between May 11 and June 7 of 2011 (Fig. 1). Sampling stations were mainly located in the ECS and only few stations were located in the southern YS to cover the buoyant plume from the Changjiang, only the ECS is provided for the name of study area in the following text. The observations were carried out from the southernmost section T (St. T3) to the northernmost section M (St. M7) from May 14 through May 27, except for the stations B1, B0, C1 and C0 located near the Changjiang Estuary, which were observed on June 2 due to the influence of typhoon "Sangda". Two representative sections, PN section (a southeast transect from the Changjiang Estuary to the Ryukyu Islands) and KWL section (northeastward section along the shelf edge of the ECS from northeast of Taiwan to PN section), were chosen to discuss the impact respectively. profiles of temperature, salinity, turbidity, and epifluorescence in the water column at grid stations. Discrete water samples were taken for nutrients, arsenic and antimony at depths determined from CTD readings. After collection, samples were filtered through precleaned 0.4- $\mu \mathrm{m}$ pore-size 
in Milli-Q water (purified with a water purification system, Millipore, USA) until a neutral $\mathrm{pH}$ was reached) in a Class-100 clean bench. Suspended particulate matter (SPM) was measured by weighing the particles trapped on the filters. The filtrates were kept in Nalgene LDPE bottles and frozen at $-20{ }^{\circ} \mathrm{C}$ until measurement. Blanks were carefully prepared by filtering on board a known volume of Milli-Q water with methods identical to those used on the bulk sample sets.

\subsection{Analytical Methods}

Dissolved arsenite and total dissolved inorganic arsenic (TDIAs, [TDIAs] $=[\mathrm{As}(\mathrm{V})]+[\mathrm{As}(\mathrm{III})]$ ) were measured using hydride generation-atomic fluorescence spectrometry (HG-AFS). Arsenite concentrations were determined at $\mathrm{pH} 5.3-5.5$ buffered by sodium citrate- $\mathrm{HCl}$ solution, in which arsenate was not allowed to be reduced to arsenite. Arsine $\left(\mathrm{AsH}_{3}\right)$ generation by the reduction of potassium borohydride $\left(\mathrm{KBH}_{4}, 0.7 \%\right)$ with flow rate of $0.6-0.7 \mathrm{ml} / \mathrm{s}$ was thus limited to the $\mathrm{As}(\mathrm{III})$ initially present in the sample. $\mathrm{AsH}_{3}$ was carried out of solution by argon gas with flow rate of 800 $\mathrm{ml} / \mathrm{min}$ and measured by AFS. TDIAs was determined with the same method with As (III) except for the acidity of $1 \mathrm{M} \mathrm{HCl}$, after reducing arsenate into arsenite by thiourea $(5 \%)-\mathrm{Vc}(3 \%)$ mixed solution for $90 \mathrm{~min}(\mathrm{Li}, 2003)$. The concentration of arsenate was calculated from the difference of TDIAs and As(III), assuming arsenic species other than arsenate and arsenite were negligible in quantity. The detection limits for TDIAs and As(III) by HG-AFS were 0.11 and $0.02 \mathrm{nM}$, respectively. The precision of HG-AFS measurement for TDIAs was $6.8 \%$ at the concentration of $1.6 \mathrm{nM}$ and for $\mathrm{As}(\mathrm{III})$ was $3.1 \%$ at the concentration of $1.3 \mathrm{nM}$. To test the robustness of the present method, the national reference standard sample (GSBZ50004-883610116, Institute for Environmental Reference Materials of Ministry of Environmental Protection) and international standard reference sample (NASS-4) were analyzed. The certified value of As in 
1 GSBZ50004-883610116 is $1.72 \pm 0.10 \mu \mathrm{g} \mathrm{L}{ }^{-1}$, and the result from our method was $1.73 \pm 0.01 \mu \mathrm{g}$

$2 \mathrm{~L}^{-1}(\mathrm{n}=7)$. The certified value of As in NASS-4 is $1.26 \pm 0.09 \mu \mathrm{g} \mathrm{L} \mathrm{L}^{-1}$, and the result from our

3 method was $1.28 \pm 0.04 \mu \mathrm{g} \mathrm{L}^{-1}$. The difference between our method and the certified value was

4 within $2 \%$, which ensures the quality of our HG-AFS method (Ren et al., 2010).

5 Dissolved antimonite (Sb(III) and total dissolved inorganic antimony (TDISb,

$6[\mathrm{TDISb}]=[\mathrm{Sb}(\mathrm{V})]+[\mathrm{Sb}(\mathrm{III})]$ ) were measured using hydride generation-atomic fluorescence

7 spectrometry (HG-AFS). Sb (III) concentrations were determined at $\mathrm{pH} 4.0-4.5$ buffered by

8 sodium citrate- $\mathrm{HCl}$ solution, in which antimonate was not allowed to be reduced to antimonite.

9 Antimony hydride $\left(\mathrm{SbH}_{3}\right)$ generation by the reduction of $\mathrm{KBH}_{4}(0.5 \%)$ with flow rate of 0.6-0.7

$10 \mathrm{ml} / \mathrm{s}$ was thus limited to the $\mathrm{Sb}$ (III) initially present in the sample. $\mathrm{SbH}_{3}$ was carried out of

11 solution by argon gas with flow rate of $600 \mathrm{ml} / \mathrm{min}$ and measured by AFS. TDISb were

12 determined with the same method with $\mathrm{Sb}$ (III) except for the acidity of $1 \mathrm{M} \mathrm{HCl}$, after reducing

13 antimonate into antimony hydride by thiourea (5\%)-Vc (3\%) mixed solution for 90 min (Wan and

14 Ren, 2011). The concentration of antimonate was calculated from the difference of TDISb and $\mathrm{Sb}$

15 (III), assuming antimony species other than antimonate and antimonite were negligible in quantity.

16 The detection limit for TDISb and Sb (III) were $0.20 \mathrm{nM}$ and $0.011 \mathrm{nM}$, respectively. The

17 precision of HG-AFS measurement for TDISb was $1.9 \%$ at the concentration of $0.25 \mathrm{nM}$ and for

$18 \mathrm{Sb}$ (III) was $5.5 \%$ at the concentration of $0.08 \mathrm{nM}$. The precision and accuracy of inorganic $\mathrm{Sb}$

19 analysis were monitored using national reference standard solution (GSB G 62043-90 (5101),

20 China National Center for Quality Supervision and Testing of Iron and Steel). The recoveries for

21 TDISb and $\mathrm{Sb}$ (III) are $93.7 \% \sim 105 \%$ and $91.1 \% \sim 104 \%$, respectively.

\section{Results}




\subsection{Hydrography}

Table 1 gives the ranges and average concentrations of temperature, salinity, SPM and different species of As and Sb. According to the horizontal distributions of temperature, salinity and suspended particulate matter (SPM) (Fig. 2a-f) and the relationships between temperature and salinity at sections PN and KWL (Fig. 3), five major water masses in the ECS during the expedition can be commonly differentiated. Changjiang Diluted Water (CDW) flows along the coast of mainland of China, which is characterized by high concentrations of nutrient and SPM and low salinity. Taiwan Strait Warm Water (TSWW) flows northward through the Taiwan Strait, which is characterized by low concentrations of nutrient and SPM and high temperature and salinity. Kuroshio intrudes onto the shelf region from the north of Taiwan and its main axis flows northward along the shelf edge of the studied area, which includes the warm, high salinity and nutrient-poor Kuroshio Surface Water (KSW) and the cold, high salinity and nutrient-rich Kuroshio Subsurface Water (KSSW) and Kuroshio Intermediate Water (KIW).

The water column was well-mixed in the shallow regions and was generally stratified in the central ECS, with relatively lower temperature and higher salinity and SPM in the bottom layer. CDW expanded southeastward in the surface and was restricted by the incursion of Kuroshio Waters (Figs. 3, 5). Another low salinity water tongue existed near the coast of Zhejiang and Fujian Provinces (here in after Zhe-Min coast) in the surface, which indicated riverine inputs (e.g. Oujiang) in the Zhejiang Province. A fairly strong vertical gradient for salinity and temperature, characteristic of the Kuroshio waters (KW), occurred at the Okinawa Trough. Kuroshio Waters occupied in the middle shelf region and shelf edge, especially in the bottom layer where the incursion of KSSW can reach $30^{\circ} \mathrm{N}$ near the Changjiang Estuary. The concentration of SPM 
1 decreased rapidly off the river mouth and showed uniform concentrations of $2-5 \mathrm{mg} \mathrm{L}^{-1}$ in the

2 shelf area. An increase in SPM concentration was observed in the bottom waters owing to

3 resuspension.

$4 \quad 3.2$ Arsenic species in the East China Sea

\subsubsection{Horizontal distribution}

The ranges and average concentrations for arsenic species in the surface and bottom layers of the ECS in the spring of 2011 are summarized in Table 1. TDIAs concentrations varied from 8.7 to $24.1 \mathrm{nM}$ in the ECS, with an average of $16.2 \mathrm{nM}$. TDIAs concentrations were high in the coastal area of the Changjiang Estuary and Hangzhou Bay and decreased rapidly off the coast in the surface, which indicated the effect of land-source input from the adjacent rivers (Fig. 4a-b). There existed mild surface depletion of TDIAs concentrations at the northern and eastern part of the study area. The concentration of TDIAs at the surface of St. D9 (located in the Okinawa trough) was 3.5-4.5 $\mathrm{nM}$ higher than the neighboring Sts. ED and DC. Horizontal distribution of TDIAs in the near bottom layer was similar to that in the surface, with relatively higher concentrations. High concentrations of TDIAs could also be seen at the near bottom of northeast of Taiwan and eastern of the study area, with low SPM contents.

17 Arsenite concentrations ranged from 0.15 to $8.52 \mathrm{nM}$ in the ECS, with an average of $0.92 \mathrm{nM}$. Arsenite showed different horizontal distribution features from TDIAs, with higher concentrations in the surface water of the upwelling region at the south of the Changjiang Estuary and the middle and eastern shelf area, corresponding to the area with surface depletion of TDIAs (Fig. 4c-d). The concentrations of As (III) in the bottom layer were significantly lower than the surface, especially at the region affected by the incursion of KSSW. The ratio of As(III)/TDIAs ranged from 0.01 to 
0.56 , with an average of 0.06 .

\subsubsection{Vertical distribution}

Sections PN (C0-CJ) and KWL (G8-CJ) with water depth >200 m and off the shelf, were chose to discuss the vertical distributions of As and the impacts of terrestrial input on the ECS shelf and material exchange between shelf water and Kuroshio Waters (Figs. 5-6). They were also used to examine the escape of terrestrial materials across the broad shelf and the impact of Kuroshio from open ocean.

In section PN, the water column was vertically well mixed in the coastal area of the Changjiang Estuary, with the characteristic of low temperature and low salinity indicating the existence of CDW, showing the influences of terrestrial waters on the shelf up to a distance of $\sim 280 \mathrm{~km}$ at Stations C5 and C7. The water column was weakly stratified in the central and eastern ECS, with warm and less saline water mass in the surface and cold and saline water mass in the bottom, indicating the impact of Kuroshio from the shelf edge (St. CJ) into the middle shelf region (between Sts. C4 and C2). The concentrations of SPM were high and well mixed in the coastal area of the Changjiang Estuary and decreased quickly offshore (Fig. 5a-c), with relatively lower concentration in the outer shelf and shelf edge. TDIAs concentrations were high and vertically homogeneous near the Changjiang Estuary, with slight segregation in the shelf region (Fig. 5d). TDIAs showed mild surface depletion and deep-water enrichment in the mid shelf and shelf break. A water mass with relatively high concentration of TDIAs occupied the bottom layer of water column at the shelf edge and intruded onto the shelf region. Arsenite showed different vertical profile with that of TDIAs, with relatively high concentration appearing at the surface of mid shelf and decreasing with depth (Fig. 5e). 
The Kuroshio forms as a northward branch of the westward North Equatorial Current at east of Luzon Island and flows northward, with a volume transport of ca. 23-37 Sv (Hsin et al., 2008 and references therein). Section KWL, originating from the north of Taiwan to the end of PN section along the Okinawa Trough, is set to discuss the possible material exchange between shelf water and Kuroshio water. In KWL section, the water column was stratified with decreasing temperature and increasing density with depth (Fig. 6a-c). There existed a water tongue with relatively higher salinity (ca. 34.7) in the water depth of 50-150 $\mathrm{m}$ of all sampling stations, which indicated the incursion of KSSW, seen in previous observations (Ren et al., 2006). SPM concentrations were low in the whole section, except for slight increasing at the top $100 \mathrm{~m}$ water layer of St. CJ (Fig. 6d). TDIAs concentrations were depleted in the surface and increased with depth generally, showing the character of the open ocean (Middelburg et al., 1988; Cutter et al., 2001; Cutter and Cutter, 2006). As (III) concentrations in the top $100 \mathrm{~m}$ water column between St. G8 and St. D9 were 8 folds lower than that in the PN section, and increased slightly towards the end of PN section (e.g. Sts. DC and CJ). As (III) concentrations in the deep water were similar with that in the PN section and showed the characteristics of deep open ocean (Fig. 6e). 3.3 Antimony species in the East China Sea

\subsubsection{Horizontal distribution} TDISb concentrations varied from 0.71 to $4.98 \mathrm{nM}$ in the ECS, with an average of $1.84 \mathrm{nM}$. Similar with the horizontal distributions of TDIAs, TDISb concentrations were high in the coastal area of the Changjiang Estuary and Hangzhou Bay and decreased rapidly off the coast both in the surface and bottom layers. Different with that of TDIAs, TDISb didn't show surface depletion and bottom enrichment. The concentrations of TDISb only moderately increased in the bottom layer of 
shelf break ( 2 $\mathrm{nM})$, which is different with that of TDIAs.

2 Antimonite concentrations ranged from BDL (below detection limit) to $0.30 \mathrm{nM}$ in the ECS,

3 with an average of $0.08 \mathrm{nM}$. Sb (III) showed patchy distributions both in surface and bottom layer,

4 with relatively higher concentrations in the coastal area of the Changjiang Estuary and extremely

5 lower concentrations in the middle shelf region in the surface. The concentrations of $\mathrm{Sb}$ (III) in the

6 bottom layer were higher than the surface (Fig. $4 \mathrm{~g}-\mathrm{h}$ ).

$7 \quad 3.3 .2$ Vertical distribution

8 In section PN, TDISb concentrations were high and vertically homogenous near the Changjiang

9 Estuary and decreased off the coast in the surface. In the bottom layer of middle shelf and shelf

10 edge where is affected by the incursion of Kuroshio Waters, TDISb concentrations remained as

11 less variable concentrations (e.g., $1.5 \mathrm{nM}$ ) as the deep water of the northwestern Pacific (Fig. 5f)

12 (Cutter and Cutter, 2006). Sb (III) were only detectable at several layers at each stations and the

13 figure is neglected here and after.

14 In KWL section, TDISb concentrations were high at St. G8 (locates at the northeast of Taiwan),

15 especially at the mid and near-bottom layer, and decreased rapidly northeastward along the flow

16 path of Kuroshio in the Okinawa Trough (Fig. 6f). Interestingly, the concentrations of TDISb at

17 the subsurface layer of St. D9 are significantly higher than the neighbored stations ED and DC

18 (2.2 nM compared to $1.7 \mathrm{nM}$ in the neighboring stations with an increase of ca. $30 \%$ ), which will

19 be discussed later.

\section{4. Discussion}

214.1 Arsenic and Antimony regimes in the East China Sea

22 4.1.1 Arsenic regime 

the result of September $2002(15.6 \pm 0.6 \mathrm{nM})$ and slightly higher than the result of September 2003 (14.2 $\pm 1.0 \mathrm{nM}$ ) (Ren et al., 2010). Average concentration of As (III) in the ECS shelf in May 2011 is $0.92 \pm 1.13 \mathrm{nM}$, which is higher than the result of September of $2002(0.65 \pm 0.23 \mathrm{nM})$ and similar with the result of September $2003(1.04 \pm 0.56 \mathrm{nM})$ (Ren et al., 2010). One thing should be kept in mind is that the station locations between different cruises mentioned above are different, with only independent sections observed in the autumn cruises (September 2002: section PN; section A, from the Changjiang Estuary to Cheju Island; section B, from the Changjiang Estuary southwards to Zhe-Min coast along the Chinese coast. September 2003: section PN; section YT, from the Changjiang Estuary to St. S1 $\left(129.15^{\circ} \mathrm{E}, 32.00^{\circ} \mathrm{N}\right)$; section AS, from St. S1 southwards to the end of section PN (St. P3, $\left.127.30^{\circ} \mathrm{E}, 28.44^{\circ} \mathrm{N}\right)$ ) and nearly uniformly covered from the north of the Changjiang Estuary southwards to the Taiwan Strait in May 2011 cruise. TDIAs concentrations are high near the coastal area of the Changjiang Estuary and Hangzhou Bay and at the bottom layer where Kuroshio Waters incursion onto the shelf. The concentration of TDIAs at Xuliujing (located at the inner Changjiang Estuary with salinity 0) was $38.1 \mathrm{nM}$ based on the field observation carried out at the early autumn of 2009 (unpublished data). Changjiang brings TDIAs along with huge amounts of fresh water and sediment into the ECS, which is believed to be the major source of TDIAs in the coasts and shallow water areas. A water tongue with high TDIAs $(17.9 \pm 2.3 \mathrm{nM})$, high salinity and extremely low SPM concentrations at the bottom of middle shelf and shelf edge suggests that the Kuroshio Waters are the other source of TDIAs in the east. The concentration of TDIAs near the Taiwan Strait was about $15.9 \pm 1.0 \mathrm{nM}$, which can be used as the background value for the TSWW. The freshwater discharges (e.g., from 
the Changjiang and other rivers in Fujian and Zhejiang provinces) mainly affected the coastal area and the surface of the shelf region, whereas the incursion of Kuroshio Waters can be tracked in middle and near bottom layer of the ECS.

Arsenite concentrations were lower than arsenate, with As (III)/TDIAs ratios ranging from 0.01 to 0.56 and with an average of $0.06 \pm 0.08$, which indicates that arsenate is the main arsenic specie in the study area. In comparison with TDIAs, As (III) showed different horizontal and vertical profiles. High arsenite concentrations were found at the surface near the Changjiang Estuary and at the surface of mid-shelf, corresponding to the area with significant surface depletion of TDIAs, which indicate different source of As (III) in the ECS shelf compared to TDIAs.

\subsubsection{Antimony regime} $0.08 \pm 0.07 \mathrm{nM}$, respectively. Concentrations of TDISb and $\mathrm{Sb}$ (III) are slightly higher or comparable with other coastal regions and open oceans in the world (Table 2), including North and South Pacific (Ellwood and Maher, 2002; Cutter and Cutter, 2006), western and eastern Atlantic Ocean (Cutter and Cutter, 1995, 1998; Middelburg et al., 1988; Cutter et al., 2001), Amazon river and its plume (Cutter et al., 2001), which indicate that the concentration of TDISb in the ECS still remained at natural levels. The concentrations of TDISb in the lower reach of the Changjiang was $10.14 \mathrm{nM}$, while they ranged from 1.39 to $6.64 \mathrm{nM}$ for the other rivers located in Zhejiang and Fujian provinces (Zhang et al., 2014). However, Sb (III) was not detectable in most stations located in the lower reaches of the Changjiang (unpublished data). Riverine discharge (e.g.

21 Changjiang and other rivers in Zhejiang and Fujian provinces) is believed to be the major source of TDISb in the coasts and shallow water areas. Kuroshio Waters have relatively lower 
concentrations of TDISb and $\mathrm{Sb}$ (III), which are not major source for $\mathrm{Sb}$ and is different with that of TDIAs.

$\mathrm{Sb}$ (III) concentrations were lower than $\mathrm{Sb}(\mathrm{V})$, with $\mathrm{Sb}$ (III)/TDISb ratios ranging from BDL to 0.21 and with average of $0.05 \pm 0.05$, which indicates that antimonate is the main antimony specie in the study area. In comparison with As (III), Sb (III) didn't show surface enrichment in the coastal area and mid-shelf region, suggesting different producing mechanisms with that of As (III).

$\mathrm{Sb}$ (III) concentrations were higher in the near bottom layer relative to surface indicate the contributions from sediment-water fluxes.

\subsection{Biogeochemical cycling of arsenic in the East China Sea}

Previous studies of arsenic biogeochemistry carried out in the Pacific (Andreae, 1979; Ellwood and Maher, 2002; Cutter and Cutter, 2006), Atlantic (Cutter and Cutter, 1995, 1998; Middelburg et al., 1988; Cutter et al., 2001), Southern Ocean (Santosa et al., 1994; Featherstone et al., 2001), Oslofjord of Norway (Abdulliah et al., 1995), continental shelf off the Gironde Estuary (Michel et al., 1997), Bohai Sea (Duan et al., 2010) and ECS shelf (Ren et al., 2010) have clearly shown linkages with phosphate cycling. The horizontal data observed in the western Atlantic Ocean suggested that arsenate uptake and the production of arsenite would increase when phosphate levels drop below ca. $0.05 \mu \mathrm{M}$ (Cutter et al., 2001).

Surface depletion of arsenate and surface maximum of arsenite in the ECS in spring of 2011

(Figs. 4-6) suggests biota mediation of arsenic as revealed in the open oceans, although marginal sea receives huge amounts of nutrients from riverine discharges and incursion of Kuroshio (Middelburg et al., 1988; Michel et al., 1997; Cutter and Cutter, 2001, 2006). Strong phytoplankton blooms occurred intermittent from April 17 through April 272011 in the coastal 
1 and northern ECS shelf according to the chlorophyll-sensing satellite images from NASA

2 (http://oceancolor.gsfc.nasa.gov/cgi/l3?.ctg=Standard\&sen=A\&prd=CHL chlor a\&per=DAY\&dat

$3 \mathrm{e}=1$ May2009\&res=4km\&num=24), with maximum chlorophyll a concentration higher than 10

$4 \mathrm{mg} / \mathrm{m}^{3}$. Figure 7 gives the vertical profiles of TDIAs, As (III) and phosphate at stations C4 and C7.

5 Water columns were slightly stratified at stations $\mathrm{C} 4$ and $\mathrm{C} 7$, with warm and less saline water at

6 top mixed layer and cold and saline water below, indicating the effects from CDW and incursion

7 of Kuroshio waters. TDIAs showed minor surface depletion and deep water enrichment like

8 phosphate in both stations, with correlation coefficients $(r)$ of 0.94 and 0.83 , respectively.

9 Figure 8 gives the correlation between As (III)/TDIAs ratio and phosphate concentrations. In general, As(III)/TDIAs ratio keeps at extremely low value when phosphate concentrations are higher than $1.00 \mu \mathrm{M}$. However, As(III)/TDIAs ratios start to increase exponentially with the decreasing of phosphate concentrations, especially when the concentrations of phosphate are lower than $0.25 \mu \mathrm{M}$. This relationship between As(III)/TDIAs ratio and phosphate concentrations indicate the role of phosphate in arsenate depletion and the production of arsenite, which is similar with previous results in other open oceans. In order to differentiate the functions of biological mediation and phosphate depletion on the arsenic speciation transformation clearly, we separate the study area into three regions according to the geographical locations and the strength of biological activity, which is coastal area (within $50 \mathrm{~m}$ isobath), northern shelf (north of $28^{\circ} \mathrm{N}$ with water depth deeper than $50 \mathrm{~m}$ ) and southern shelf (south of $28^{\circ} \mathrm{N}$ with water depth deeper than 50 m) (Fig. 8). According to the chlorophyll-sensing satellite images from NASA, the bloom mainly occurred at the coastal area and the region north of $28^{\circ} \mathrm{N}$, which is corresponding to the area with significant As (III) surface enrichment (Fig. 4c). As(III)/TDIAs ratios remain at relatively lower 
values in the southern ECS with weak phytoplankton activity. However, As(III)/TDIAs ratios increase dramatically with the decreasing of phosphate concentrations in the coastal and northern ECS where phytoplankton activities were high. Plots of As (V) against phosphate levels show good correlations in the stations with significant TDIAs depletion in May 2011, with the stoichiometric molar ratios of As(V):P ranging from

$61.2 \times 10^{-3}$ to $20.9 \times 10^{-3}$ and an average of $10.8 \times 10^{-3}$. The stoichiometric molar ratios of $\mathrm{As}(\mathrm{V}): \mathrm{P}$ are 7 relatively high in the inner and middle shelf and lower at the shelf edge. Previous observations 8 carried out in the PN section of ECS shelf in autumn 2002 and 2003 gave the molar ratios of $92.42 \times 10^{-3}$ and $2.06 \times 10^{-3}$, respectively (Ren et al., 2010). In order to compared the results of the ECS between different seasons and years conveniently, the stoichiometric molar ratios of As(V):P 11 at PN section in May 2011 are calculated, with average of $12.3 \times 10^{-3}$. These values in May 2011 are significantly higher than the results of autumn 2002 and 2003, indicate higher arsenate stress appeared in May 2011 compared to September 2002 and 2003 in the ECS shelf. The results are higher than North and South Atlantic Ocean $\left(2.5 \times 10^{-3}\right.$, Cutter and Cutter, 1995), western Atlantic Ocean $\left((2.63 \pm 0.4) \times 10^{-3}\right.$, Cutter et al., 2001) and fjords of Norway $\left(2.54 \times 10^{-3}\right.$ to $3.16 \times 10^{-3}$, Abdullah et al., 1995), while similar with the $10 \times 10^{-3}$ in the North Pacific where Andreae (1979) found evidence of arsenate stress. 4.3 Biogeochemical cycling of antimony in the East China Sea Most previous studies of antimony from Atlantic Ocean, Pacific Ocean and adjacent seas showed either conservative or mildly scavenged behavior like aluminum and also showed the importance of atmospheric deposition on both vertical and horizontal distributions (Andreae and 
1 Cutter, 1995; Cutter et al., 2001; Cutter and Cutter, 2006). A confounding issue should be kept in

2 mind is that anthropogenic emissions will increase the concentration of $\mathrm{Sb}$ in atmospheric

3 deposition. Cutter and Cutter (2006) found that there existed linear correlation between the

4 concentrations of $\mathrm{Al}$ and $\mathrm{Sb}$ at station $\mathrm{ALOHA}\left(22.75^{\circ} \mathrm{N}, 158.0^{\circ} \mathrm{W}\right.$; farthest away from potential

5 anthropogenic inputs) with atomic $\mathrm{Sb} / \mathrm{Al}$ ratio of 0.09 . However, the correlations between TDISb

6 and $\mathrm{Al}$ decreased for the stations located at the western North Pacific where received more

7 anthropogenic Sb relative to $\mathrm{Al}$ (Cutter and Cutter, 2006).

TDISb negatively correlates with salinity (with salinity range of 23.40 and 34.90), with fitting

equation of $y=-0.2528 x+10.18$ and linear relationship coefficient of $0.75(n=310$, figure is not

shown), which is similar with the previous result of the coastal area of Zhe-Min coast (Zhang et al.,

112014 ) and indicates that physical mixing of different water masses is the major influencing factor

of the biogeochemical behavior of TDISb. There are no apparent correlations between TDISb and

SPM, DO and phosphate (figures are not shown) in the ECS in May 2011, neither for $\mathrm{Sb}(\mathrm{III}) / \mathrm{Sb}(\mathrm{V})$ and TDISb in the ECS in May $2011(r=0.43, \mathrm{n}=310)$ with atomic Sb/Al ratio of 0.011, which is lower than the results from station ALOHA (Cutter and Cutter, 2006). The relatively lower atomic $\mathrm{Sb} / \mathrm{Al}$ ratio compared to station ALOHA is mainly due to higher concentration of dissolved $\mathrm{Al}$ compared to $\mathrm{Sb}$ in the marginal seas. section KWL where affected by the incursion of Kuroshio from south to north. In order to compare the vertical profiles of TDISb in the ECS with the open ocean, TDISb results from station 
1 Current, western North Pacific, Cutter and Cutter, 2006) are redrew and included in Figure 9.

2 Compared to St. 1 in the western North Pacific, TDISb concentrations at St. G8 are significantly

3 higher in the subsurface layer (50-200 m) and middle layer (400-800 m). Salinities of water

4 column of St. G8 with layer at $\sigma_{\mathrm{T}}$ value 23.63 and 24.06 (corresponding to the water depth of nearly 95-120 m) and 24.51 and 25.00 (corresponding to the water depth of nearly 175-205 m) are significantly lower than the other stations in section KWL within similar isopycnal intervals.

7 However, salinities of seawater with $\sigma_{\mathrm{T}}$ value larger than 26.31 (corresponding to the water depth 8 of 400-1000 m) are significantly higher than the other stations (Fig. 3). The difference between St.

9 G8 and other stations in T-S diagram of section KWL (Fig. 3) might indicate the contributions from the South China Sea (SCS) (Chen, 2005). South China Sea Tropical Water (SCSTW) and

11 South China Sea Intermediate Water (SCSIW), outflowing modified Kuroshio waters from the SCS through Luzon Strait and with the characteristic of salinity maximum within the water depth of 50-150 m and comparatively higher salinity minimum within the water depth of 350 and 1350 $\mathrm{m}$ deep, contains more nutrients than does the Kuroshio Waters due to the strong upwelling in the SCS basin (Nitani, 1972; Chen and Wang, 1998; Chen, 2005). The existence of the impacts from SCSTW and SCSIW might explain the relative higher concentrations of TDISb at subsurface layer and 400-800 m layer due to the contributions from the SCS. Along with the northward movement of Kuroshio, the concentrations of TDISb are decreased by the sequence of St. ED and St. DC (except for St. D9) and closed to the value of Station 1 due to the dilution of Kuroshio. Vertical profile of TDISb at station DC, the deepest station in section KWL (1588 m, bottom sample was not collected due to the technical problems) which means receiving lest impact from continental shelf, is nearly coincide with the profile of St.1 except for 
the surface enrichment. Surface enrichment of TDISb at station DC compared to St. 1 is mainly due to the reception of terrestrial material from riverine and atmospheric deposition and represents the characteristics of marginal seas.

Vertical profile of TDISb at St. D9 doesn't follow the general variation along with the northward movement of Kuroshio and shows abnormally higher concentrations at top $200 \mathrm{~m}$ layer and similar profile with St. DC at the water column deeper than $200 \mathrm{~m}$ (1.94 nM compared to 1.47 $\mathrm{nM}$ with an increase of ca. 30\%). Atmospheric deposition solely can't explain the enrichment of TDISb within top $200 \mathrm{~m}$ water column, and will be discussed later. The existence of cross shelf transport from ECS shelf to the Kuroshio can be the possible reason and we really found the evidence from the distributions of dissolved $\mathrm{Al}$ (unpublished data). The contribution of cross shelf transport from marginal seas to the open ocean needs to be paid more attention.

\subsection{Antimony budgets in the East China Sea}

Arsenic budgets in the summer for the ECS was evaluated before based on box models for the conservation of water and salt masses and are not re-evaluate in this manuscript (Ren et al., 2010). Antimony budgets in the ECS are evaluated and listed in Table 3, based on the water budgets in the summer summarized by Zhang et al. (2007) and simplified one-box model descripted by Gordon et al. (1996). The major potential sources of antimony into the ECS include river runoff (mainly from Changjiang discharge which accounts for ca. 90-95\% of total riverine discharges and neglect the contributions from other rivers); the intrusion of oceanic water from the Kuroshio (from north of Taiwan, mainly composed of the KSW (i.e., 25\%) and the KSSW (i.e., 75\%)); the water flux through the Taiwan Strait (TSWW) and atmospheric deposition (both dry and wet deposition). The outflow of antimony is mainly accompanied by the water exchange between the 
1 Yellow Sea and the ECS and with currents through the Tsushima/Korea Strait. The contributions

2 from submarine groundwater discharge (SGD) and sediment water interface are ignored in Table 3

3 due to lack of relevant data.

$4 \quad$ The range and average concentration of TDISb for the Changjiang are from our ongoing monitoring station (Xuliujing, i.e. $160 \mathrm{~km}$ inland from the river mouth with salinity of $\sim$ ), which was monitored every month from July 2012 to June 2013, with average of 11.4 nM (unpublished data). The influx from other rivers was not included owing to their minor contribution. The mean concentrations of TDISb in the top $50 \mathrm{~m}$ and a depth interval of 50-200 $\mathrm{m}$ at stations located at the section of KWL were taken as the KSW and KSSW (Nitani, 1972; Wong et al., 2000). The average concentration of TDISb at stations T1 and T3 are used as the end-member of TDISb for the inflow from the Taiwan Strait (TSWW).

Recent results from peat bogs and ice cores have demonstrated that anthropogenic sources of $\mathrm{Sb}$ have dominated the atmospheric inputs to the open ocean at least 700 years (Krachler et al., 2008 and references therein). The atmospheric deposition flux of Sb should be included in budgetary work considering the reasons that China is an important producing country of Sb products in the world and significant annual aerosol transport from mainland Asia to the North Pacific $(\sim 480 \times$ $10^{12} \mathrm{~g} \mathrm{yr}^{-1}$, Duce et al., 1991). The atmospheric Sb concentrations in the ECS based on the aerosol samples collected during cruises between the spring of 2005 and the spring of 2007 were $2.8 \mathrm{ng}$ $\mathrm{m}^{-3}(\mathrm{n}=7), 1.1 \mathrm{ng} \mathrm{m}^{-3}(\mathrm{n}=33)$ and $0.8 \mathrm{ng} \mathrm{m}^{-3}(\mathrm{n}=7)$ for winter, spring and summer, respectively (Hsu et al., 2010). There were no aerosol samples collected in autumn. The average atmospheric Sb concentration in the ECS is $1.57 \pm 1.08 \mathrm{ng} \mathrm{m}^{-3}$ if we assume the concentration in autumn is similar with that of summer. Mean dry deposition velocity for aerosol particles of Sb in the ECS 
1 was $2.0 \pm 1.5 \mathrm{~cm} \mathrm{~s}^{-1}$ based on mass particle-size distributions and other observation and model

2 calculation (Uematsu et al., 1985; Duce et al., 1991; Gao et al., 1997; Hsu et al., 2009). Then, the

3 dry deposition fluxes of Sb in ECS can be estimated by the formula of $F=V_{d} \times C_{a}$, in which $V_{d}$

4 represents the dry deposition velocity and $C_{a}$ represents the atmospheric concentration of $\mathrm{Sb}$, with

5 the result of $0.050 \pm 0.02 \mathrm{~mol} \mathrm{~s}^{-1}$ considering the average solubility of $\mathrm{Sb}$ from aerosol samples as

$636 \pm 7 \%$ (Hsu et al., 2010). Due to the absence of wet deposition data for Sb in the ECS, total

7 atmospheric deposition flux of $\mathrm{Sb}$ is estimated to be $0.18 \pm 0.09 \mathrm{~mol} \mathrm{~s}^{-1}$ assuming that the

8 proportion of dry and wet deposition flux of $\mathrm{Sb}$ is similar with that of annual eolian dust fluxes

9 through dry (27\%) and wet (73\%) deposition (Hsu et al., 2009) and the solubility of Sb in the dry

and wet deposition is same. Total atmospheric input of Sb into the East China Sea is nearly half of

11 the input from the rivers, with obvious seasonal and sporadic characteristics. However, the atmospheric deposition of Sb maybe underestimated due to the ignorance of significant contributions from rainwater which can flush out trace elements from aerosol particles thoroughly

14 (Ren et al., 2011) and need to be studied in the near future.

Table 3, which are different with the mass balance results of arsenic (Ren et al., 2010). In case of arsenic, the input is higher than output with a value of $9.9 \mathrm{~mol} \mathrm{~s}^{-1}$ which indicates the net sinks of arsenic due to the species transformation and burial into the sediments. However, antimony is quite conservative compared to arsenic, which is same with the discussion before.

\section{Conclusions}

21 The concentrations of dissolved arsenic and antimony in the ECS are comparable to the other marginal area and open ocean, which demonstrate that the potential anthropogenic impacts from 
the mainland of China are not significantly affect the background concentration. For dissolved inorganic arsenic (III, V) and antimony (III, V) examined in the ECS, all display the effects from riverine inputs, atmospheric deposition, intrusion of Kuroshio Waters and Taiwan Strait Warm

4 Waters. Pentavalent (arsenate and antimonite), the thermodynamically form, are the major speciation in the ECS in spring for both arsenic and antimony. TDIAs shows moderate surface depletion and bottom enrichment profiles like phosphate, with significant surface maximum of As

7 (III) in the region with lower concentration of phosphate. High $\mathrm{As}(\mathrm{V}) / \mathrm{P}$ atomic ratio have been 8 observed in spring of the ECS, which is four to five folds higher than the results of ECS shelf in autumn 2002 and 2003 and indicates more arsenate stress in spring. In contrast, antimony showed moderate scavenged and conservative profiles in the ECS, with less evidence of biological mediation. The variations of horizontal and vertical profiles of $\mathrm{Sb}(\mathrm{V})$ are sensitive to the atmospheric deposition and riverine inputs, which make it a good tracer for the transport of terrestrial material. Vertical profiles of TDISb at KWL section, originating from northeast of Taiwan and northeastward along with the current of Kuroshio, suggests the significant contributions from SCSTW and SCSIW and indicates the possible position of cross shelf transport from ECS to the Kuroshio. Box model calculation of antimony in the ECS demonstrates that the major sources of $\mathrm{Sb}$ are riverine input, atmospheric deposition, the incursion of Kuroshio and water flux through Taiwan Strait (TSWW), and the major sinks are through the outflow currents through the Tsushima/Korea strait. The input and output fluxes of Sb are nearly balanced which demonstrate the rationality of box model calculation.

\section{Acknowledgement}


1 This study was funded by National Basic Research Program of China (973 project,

2 2011CB409801), National Science Foundation of China (41176096) and the Program of

3 International S\&T Cooperation (No. 2010DFA24590). The authors thank the captain and crew of

$4 R / V$ "Shiyan 3", X.H. Cao and C.L. Xin for their assistance in the field and laboratory work, Z.W.

5 Wang for his assistance of figure preparation. Drs. J. Li and R.F. Zhang are acknowledged for their

help of hydrographic data managements during the execution of 973 project.

7

\section{$8 \quad$ References}

Abdullah, M. I., Zhou, S. Y., Kare, M., 1995. Arsenic and selenium species in the oxic and anoxic waters of the Oslofjord, Norway. Mar. Pollut. Bull. 31, 116-126.

Andreae, M. O., Froelich, P. N., 1984. Arsenic, antimony, and germanium biogeochemistry in the Baltic Sea. Tellus Ser. B 36, 101-117.

Andreae, M.O., 1979. Arsenic speciation in seawater and interstitial waters: the influence of biological - chemical interactions on the chemistry of a trace element. Limnol. Oceanogr. 24, $440-452$.

Andreae, M.O., Klumpp, D., 1979. Biosynthesis and release of organo-arsenic compounds by marine algae. Environ. Sci. and Technol. 13, 738-741.

Carlin Jr., J.F., 2000. Antimony. U.S. Geological Survey Mineral Commodity Summaries.

Chang, P.H., Isobe, A., 2003. A numerical study on the Changjiang diluted water in the Yellow and East China Seas. J. Geophy. Res. 108, C9, 3299, doi:10.1029/2002JC001749.

Chen, C.-T. A., 2005. Tracing tropical and intermediate waters from the South China Sea to the Okinawa Trough and beyong. J. Geophys. Res. 110, C05012, doi:10.1029/2004JC002494.

Chen, C.-T. A., Wang, S. L., 1998. Influence of intermediate water in the western Okinawa Trough by the outflow from the South China Sea. J. Geophys. Res. 103, 12683- 12688.

Chen, C.-T.A., Zhai, W., Dai, M., 2008. Riverine input and air-sea $\mathrm{CO}_{2}$ exchanges near the Changjiang (Yangtze River) Estuary: Status quo and implication on possible future changes in metabolic status. Cont. Shelf Res. 28, 1476-1482.

Cutter, G.A., Cutter, L.S., 1995. Behavior of dissolved antimony, arsenic, and selenium in the Atlantic Ocean. Mar. Chem. 49, 295-306. 
Cutter, G.A., Cutter, L.S., Featherstone, A.M., Lohrenz, S.E., 2001. Antimony and arsenic biogeochemistry in the western Atlantic Ocean. Deep Sea Res. Part II 48, 2895-2915.

Cutter, G.A., Cutter, L.S., 2006. Biogeochemistry of arsenic and antimony in the North Pacific Ocean. Geochem. Geophys. Geosyst. 7(5), doi: 10.1029/2005GC001159.

Cutter, G.A., Cutter, L.S., 1998. Metalloids in the high latitude North Atlantic Ocean: sources and internal cycling. Mar. Chem. 61, 25-36.

Duan, L.Q., Song, J.M., Li, X.G., Yuan, H.M., 2010. The behaviors and sources of dissolved arsenic and antimony in Bohai Bay. Cont. Shelf Res. 30(14), 1522-1534.

Duce, R. A., et al., 1991. The atmospheric input of trace species to the world ocean. Global Biogeochem. Cycles 5, 193-259, doi:10.1029/91GB01778.

Ellwood, M. J., Maher, W.A., 2002. Arsenic and antimony species in surface transects and depth profiles across a frontal zone: The Chatham Rise, New Zealand. Deep Sea Res. Part I 49, 1971-1981.

Featherstone, A.M., Butler, E.C., Grady, B.V.O., 2001. Meridional distribution of arsenic species in the subantarctic zone of the Southern Ocean, south of Australia. J. Geophy. Res. 106 (C12),31657-31667.

Filella, M., Belzile, N., Chen, Y.W., 2002. Antimony in the environment: a review focused on natural waters I. Occurrence. Earth-Science Reviews 57, 125-176.

Gao, Y., Arimoto, R., Duce, R.A., Zhang, X.Y., Zhang, G.Y., An, Z.S., Chen, L.Q., Zhou, M.Y., Gu, D.Y., 1997. Temporal and spatial distributions of dust and its deposition to the China Sea. Tellus Ser. B, 49, 172- 189 .

Gong, G.C., Chen, Y.L.L., Liu, K.K., 1996. Chemical hydrography and chlorophyll a distribution in the East China Sea in summer: implications in nutrient dynamics. Cont. Shelf Res. 16, 1561 - 1590.

Gordon, D.C., Boudreau, P.R., Mann, K.H., Ong, J.-E., Silvert, W.L., Smith, S.V., Wattayakorn, G., Wulff, F., Yanagi, T.,1996. LOICZ biogeochemical modeling guidelines. LOICZ Reports and Studies 5, LOICZ, Texel, The Netherlands.

Guieu, C., Zhang, J., Thomas, A.J., Martin, J.M., Brun-Cottan, J.-C., 1993. Significance of atmospheric fallout on the upper layer water chemistry of the North-Western Mediterranean. J. Atmos. Chem. $17,45-60$.

Guo, X., Miyazawa, Y., Yamagata, T., 2006. The Kuroshio onshore intrusion along the shelf break of 
the East China Sea: the origin of the Tsushima Warm Current. J. Phys. Oceanogr. 36(12), 2205-2231, doi:10.1175/JPO2976.1.

He M., Wan, H., 2004. Distribution, speciation, toxicity and bioavailability of antimony in the environment. Prog. in Chem. 16(1), 131-135. (in Chinese with English abstract)

Hellweger, F.L., Farley, K.J., Lall, U., Di Toro, D.M., 2003. Greedy algae reduce arsenate. Limnol. Oceanogr. 48, 2275-2288.

Hsin, Y.C., Wu, C.R., Shaw, P.T., 2008. Spatial and temporal variations of the Kuroshio east of Taiwan, 1982-2005: A numerical study. J. Geophys. Res. 113, C04002, doi:10.1029/2007JC004485.

Hsu, S. C., Wong, G.T.F., Gong, G.C., Shiah, F.K., Huang, Y.T., Kao, S.J., Tsai, F., Lung, S.C.C., Lin, F.J., Lin, I.I., Hung, C.C., Tseng, C.M., 2010. Sources, solubility and dry deposition of aerosol trace elements over the East China Sea. Mar. Chem. 120, 116-127.

Hsu, S.C., Liu, S.C., Arimoto, R., Liu, T.H., 2009. Dust deposition to the East China Sea and its biogeochemical implications. J. Geophy. Res. 114, D15304, doi:10.1029/2008JD011223.

Huang, W.W., Martin, J.M., Seyler, P., Zhang, J., Zhong, X.M., 1988. Distribution and behavior of arsenic in the Huanghe (Yellow River) estuary and Bohai Sea. Mar. Chem. 25(1), 75-91.

Ichikawa, H., Chaen, M., 2000. Seasonal variation of heat and freshwater transports by the Kuroshio in the East China Sea. J. Mar. Syst. 24, 119 - 129.

Krachler, M., Zheng, J.C., Fisher, D., Shotyk, W., 2008. Atmospheric Sb in the Arctic during the past 16,000 years: responses to climate change and human impacts. Global Biogeochem. Cycles 22, GB1015, doi:10.1029/2007GB002998.

Li, D.D., 2003. Modification of atomic fluorescence determination of arsenic in natural waters, with application in Jiaozhou Bay, Yellow Sea and East China Sea. Master D. thesis, Ocean University of China, Qingdao. (In Chinese, with English abstract)

Li, Q., Yu, M., Lu, G., Cai, T., Bai, X., Xia, Z., 2011. Impacts of the Gezhouba and Three Gorges reservoirs on the sediment regime in the Yangtze River, China. J. Hydrol. 403, 224-233.

Li, L., Ren, J.L., Yan, Z., Liu, S.M., Wu, Y., Zhou, F., Liu, C.G., Zhang, J., 2014. Behavior of arsenic in the coastal area of Changjiang (Yangtze River) Estuary: Influences of water mass mixing, the spring bloom and hypoxia. Cont. Shelf Res. 80(1), 67-78.

Liu, S. M., Zhang, J., Chen, S. Z., Chen, H. T., Hong, G. H., Wei, H., Wu, Q. M., 2003. Inventory of 
nutrient compounds in the Yellow Sea. Cont. Shelf Res. 23, 1161-1174.

Michel, P., Boutier, B., Herbland A., Averty, B., Artigas, L.F., Auger, D., Chartier, E., 1997. Behavior of arsenic on the continental shelf off the Gironde estuary: role of phytoplankton in vertical fluxes during spring bloom conditions. Oceanol. Acta 21(2), 325-333.

Middelburg, J.J., Hoede, D., van der Sloot, H.A., van der Weijden, C.H., Wijkstra, J., 1988. Arsenic, antimony and vanadium in the North Atlantic Ocean. Geochim. Cosmochim. Acta 52, 2871 2878.

Milliman, J.D., Meade, R.H., 1983. World-wide delivery of river sediment to the oceans. J. Geol. 91 (1), $1-21$

Millward, G.E., Kitts, H.J., Comber, S.D.W., Ebdon, L., Howard, A.G., 1996. Methylated arsenic in the southern North Sea. Estuar., Coast. Shelf Sci. 43, 1-18.

Neff, J.M., 1997. Ecotoxicology of arsenic in the marine environment. Environ. Toxicol. Chem. 16, 917-927.

Nitani, H., 1972. Beginning of the Kuroshio, in Kuroshio: Its Physical Aspects, edited by Stommel, H., Yoshida, K., pp. 129 - 163, Univ.Tokyo Press, Tokyo.

Nriagu, J.O., 1989. A global assessment of natural sources of atmospheric trace metals. Nature 338: 47-49.

Oremland, R.S., Dowdle, P.R., Hoeft, S., Sharp, J.O., Schaefer, J.L., Miller, L.G., Blum, J.S., Smith, R.L., Bloom, N.S., Wallschlaeger, D., 2000. Bacterial dissimilatory reduction of arsenate and sulfate in meromictic Mono Lake, California. Geochim. Cosmochim. Acta 64, 3073-3084.

Oremland, R.S., Stolz, J.F., 2003. The ecology of arsenic. Science 300, 939-944.

Ren, J.L., Zhang, G.L., Zhang, J., Shi, J.H., Liu, S.M., Li, F.M., Jin, J., Liu, C.G., 2011. Distribution of dissolved aluminum in the Southern Yellow Sea: Influences of a dust storm and the spring bloom. Mar. Chem. 125, 69-81. doi:10.1016/j.marchem.2011.02.004

Ren, J.L., Zhang, J., Li, D.D., Cheng, Y., Liu, S.M., 2010. Behavior of dissolved inorganic arsenic in the Yellow Sea and East China Sea. Deep-Sea Res. II 57, 1035-1046.

Ren, J.L., Zhang, J., Li, J.B., Yu, X.Y., Liu, S.M., Zhang, E.R., 2006. Dissolved aluminum in the Yellow Sea and East China Sea - Al as a tracer of Changjiang (Yangtze River) discharge and Kuroshio incursion. Estuar., Coast. Shelf Sci. 68, 165-174.

Sanders, J.G., Riedel, G.F., 1993. Trace element transformation during the development of an estuarine 
algal bloom. Estuaries 16, 521-531.

Santosa, S. J., Wada, S., Tanaka, S., 1994. Distribution and cycle of arsenic compounds in the ocean. Appl. Organomet. Chem. 8, 273-283.

Shotyk, W., Cheburkin, A.K., Appleby, P.J., Fankhauser, A., Kramers, J.D., 1996. Two thousand years of atmospheric arsenic, antimony, and lead deposition recorded in an ombrotrophic peat bog profile, Jura Mountains, Switzerland. Earth Planet. Sci. Lett. 145, E1-E7.

Su, J. L., Pan, Y. Q., 1987. On the shelf circulation north of Taiwan. Acta Oceanol. Sin. 6(Supp. 1), 1-20.

Teague, W. J., Hwang, P. A., Jacobs, G. A., Book, J. W., Perkins, H. T., 2005. Transport variability across the Korea/Tsushima Strait and the Tsushima Island wake. Deep Sea Res. II 52(11), 1784-1801, doi:10.1016/j.dsr2.2003.07.021.

Uematsu, M., Duce, R.A., Prospero, J.M., 1985. Deposition of atmospheric mineral particles in the North Pacific Ocean. J. Atmos. Chem. 3, 123-128, doi:10.1007/BF00049372.

Van der Weijden, C.H., Middelburg, J.J., De Lange, G.J., van der Sloot, H.A., Hoede, D., Woittiez, J.R.W., 1990. Profiles of the redox-sensitive trace elements As, Sb, V, Mo and U in the Tyro and Bannock Basins Žeastern Mediterranean. Mar. Chem. 31, 171-186.

Wan, Y.X., Ren, J.L., 2011. Determination of major antimony species (Sb(V) and $\mathrm{Sb}(\mathrm{III})$ ) in natural water by hydride generation atomic fluorescence spectrometry. Mar. Sci. 35(4), 37-43 (in Chinese with English abstract).

Wang, H., Saito, Y., Zhang, Y., Bi, N., Sun, X., Yang, Z., 2011. Recent changes of sediment flux to the western Pacific Ocean from major rivers in East and Southeast Asia. Earth-Sci. Rev. 108, 80-100.

Wang, X., He, M., Xi, J., Lu, X., 2011. Antimony distribution and mobility in rivers around the world's largest mine of Xikuangshan, Huan Province, China. Microchem. J. 97, 4-11

Wang, X., Wang, J.P., Liu, C.H., Zhang, F.F., 2014. Situation analysis and sustainable development strategy of antimony resources of China. China Min. Mag. 23(5): 9-13 (in Chinese with English abstract).

Wong, G.T.F., Chao, S.Y., Li, Y.H., Shiah F.K., 2000. The Kuroshio edge exchange processes (KEEP) study - an introduction to hypotheses and highlights. Cont. Shelf Res. 20, 335-347.

Wurl, O., Zimmer, L., Cutter, G.A., 2013. Arsenic and phosphorus biogeochemistry in the ocean: Arsenic species as proxies for P-limitation. Limnol. Oceanogr. 58, 729-40. 
Xiao, X.Y., Chen, T.B., Liao, X.Y., Wu, B., Yan, X.L., Zhai, L.M., Xie, H., Wang L.X., 2008. Regional distribution of arsenic contained minerals and arsenic pollution in China. Geograph. Res. 27(1), 201-212 (in Chinese with English abstract).

Yao, Q.Z., Zhang, J., Qin, X.G., Xiong, H., Dong, L.X., 2006. The behavior of selenium and arsenic in the Zhujiang (Pearl River) Estuary, South China Sea. Estur., Coast. Shelf Sci. 67(1-2), 170-180.

Yao, Q.Z., Zhang, J., Wu, Y., Xiong, H., 2007. Hydrochemical processes controlling arsenic and selenium in the Changjiang River (Yangtze River) system. Sci. Total Environ. 377(1), 93-104.

Zhang, J., Liu, S.M., Ren, J.L., Wu, Y., Zhang, G.L., 2007. Nutrient gradients from the eutrophic Changjiang (Yangtze River) Estuary to the oligotrophic Kuroshio waters and re-evaluation of budgets for the East China Sea Shelf. Progr. in Oceanogr. 74, 449-478.

Zhang, J., Su, J. L., 2004. Nutrient dynamics of the China Seas: The Bohai Sea, Yellow Sea, East China Sea and South China Sea. In: Robinson, A., Brink, K. (Eds.), The Sea. Press of Harvard University, USA. 14: Chapter 14-17.

Zhang, X.Z., Ren, J.L., Liu, Z.G., Fan, X.P., Liu, C.G., Wu, Y., 2014. Distributions and influencing factors of total dissolved inorganic antimony in the coastal area of Zhejiang and Fujian. Environ. Sci. 35(2): 547-554. (in Chinese with English abstract) 


\section{Captions of figures:}

Figure 1. Sampling locations of the East China Sea for the May 2011 cruise, with illustrations of circulation regimes including Changjiang Diluted Water (CDW); Kuroshio Water (KW) and Taiwan Stait Warm Water (TSWW). Abbreviation of TAS represents Taiwan Strait. Sections of PN and KWL are highlighted as bold dashed lines.

Figure 2. Horizontal distributions of temperature, salinity and SPM (mg/l) in the surface and bottom layer of the East China Sea.

Figure 3. Relationships between temperature and salinity of seawater for sections PN and KWL. Isopycnals are shown. CDW, the Changjiang Diluted Water; TSWW, the Taiwan Strait Warm Water; KSW, the Kuroshio Surface Water; KSSW, the Kuroshio Subsurface Water; KIW, the Kuroshio Intermediate Water; SMW, the Shelf Mixed Water. The definitions of the water masses are based on Gong et al. (1996) and Ichikawa and Chaen (2000).

Figure 4. Horizontal distributions of TDIAs, As (III), TDISb and Sb (III) (nM) in the surface and bottom layer of the East China Sea.

Figure 5. Vertical profiles of temperature, salinity, SPM (mg/l), TDIAs (nM), As(III) (nM) and TDISb (nM) at PN section in the East China Sea. Note the difference in scales of depths above and below $150 \mathrm{~m}$.

Figure 6. Vertical profiles of temperature, salinity, SPM (mg/l), TDIAs (nM), As(III) (nM) and TDISb (nM) at KWL section in the East China Sea.

Figure 7. Vertical profiles of temperature, salinity, TDIAs, As(III) and phosphate at stations C4 and $\mathrm{C7}$ in the East China Sea.

Figure 8. Relationship between As(III)/TDIAs ratio and phosphate in spring of 2011 in the East China Sea. Data are separated into three groups: coastal region, indicates the stations locate within $50 \mathrm{~m}$ isobaths in the ECS and $20 \mathrm{~m}$ isobaths in the YS; Northern Shelf and Southern Shelf, indicate the stations locate at the north and south of latitude $28^{\circ} \mathrm{N}$ in the ECS shelf and shelf break area, respectively. According to the chlorophyll-sensing satellite images from NASA (http://oceancolor.gsfc.nasa.gov/cgi/13?ctg=Standard\&sen=A\&prd=CHL_chlor_a\&per=DAY

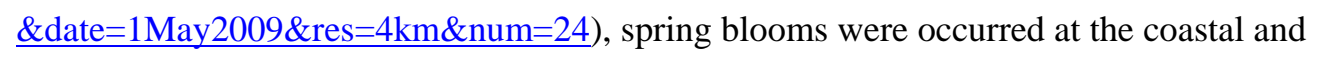


northern ECS during April 17 and 27. Dashed line is the regression between As(III)/TDIAs and phosphate for the group of Northern Shelf.

Figure 9. Vertical profiles of TDISb at stations G8, ED, D9, DC in the East China Sea. Station 1 $\left(34.467^{\circ} \mathrm{N}, 146.99^{\circ} \mathrm{E}\right.$, locates at the northern edge of the subtropical gyre in the Kuroshio Current, western North Pacific, Cutter and Cutter, 2006) are redrew for the comparison. 


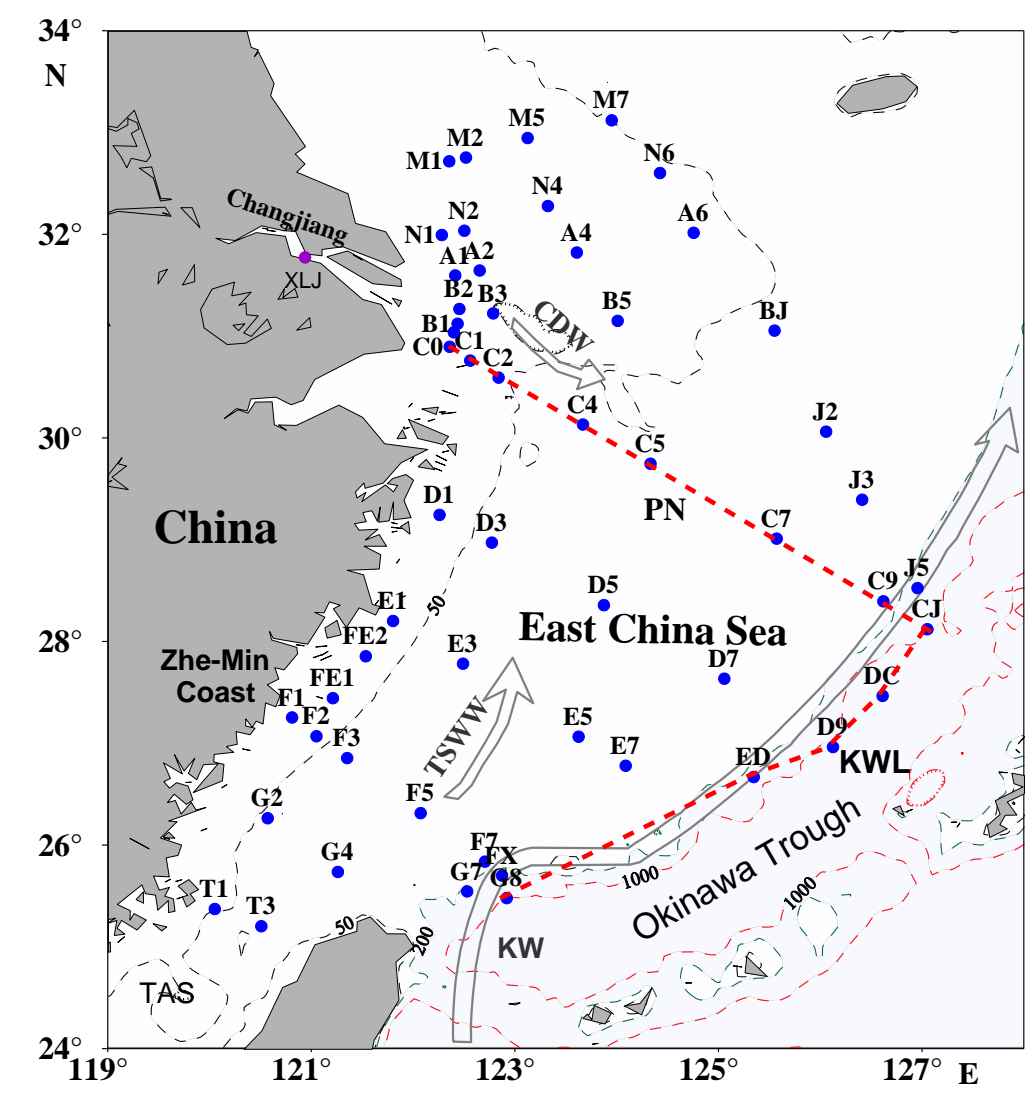

2 Fig. 1

3 

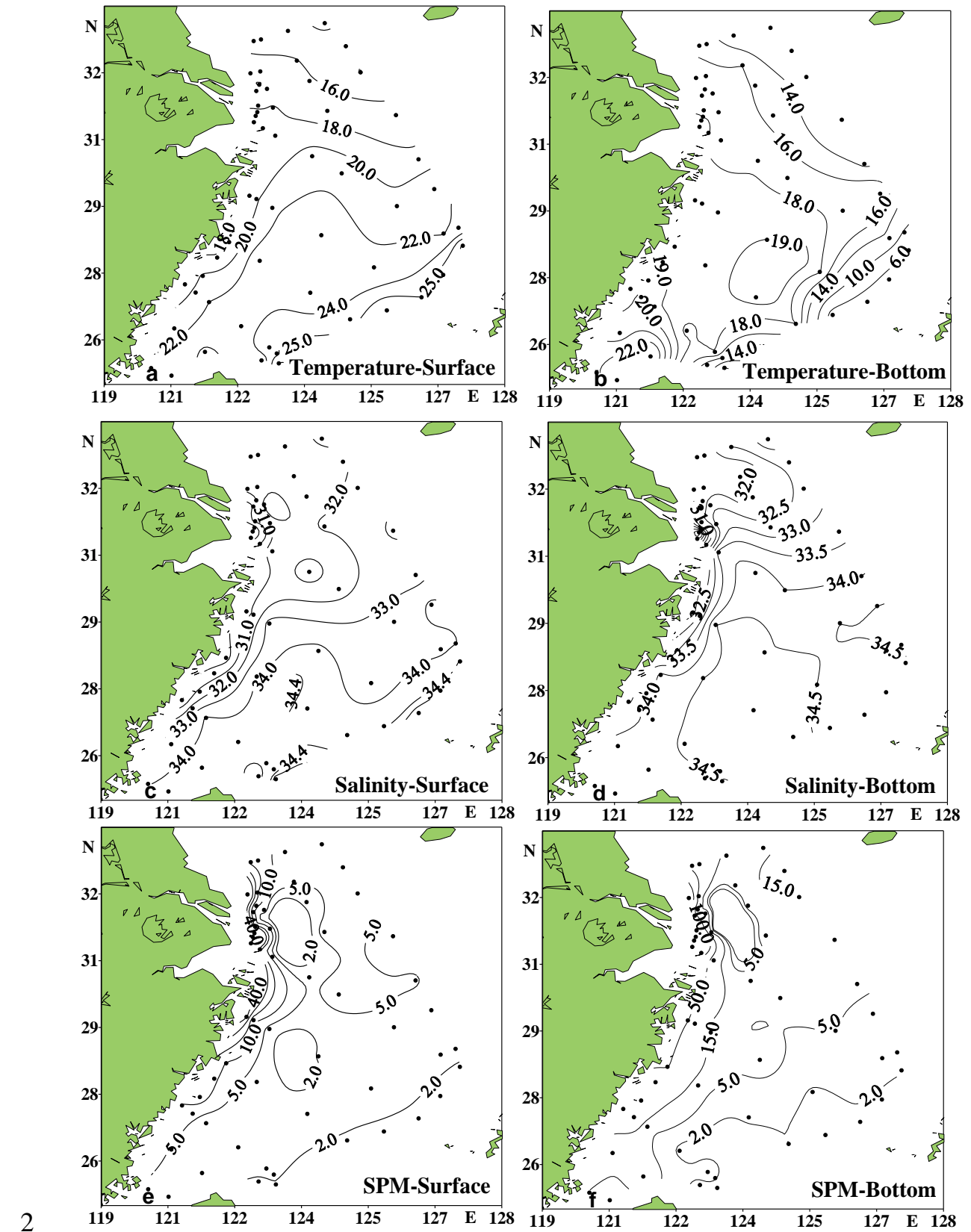

Fig. 2 

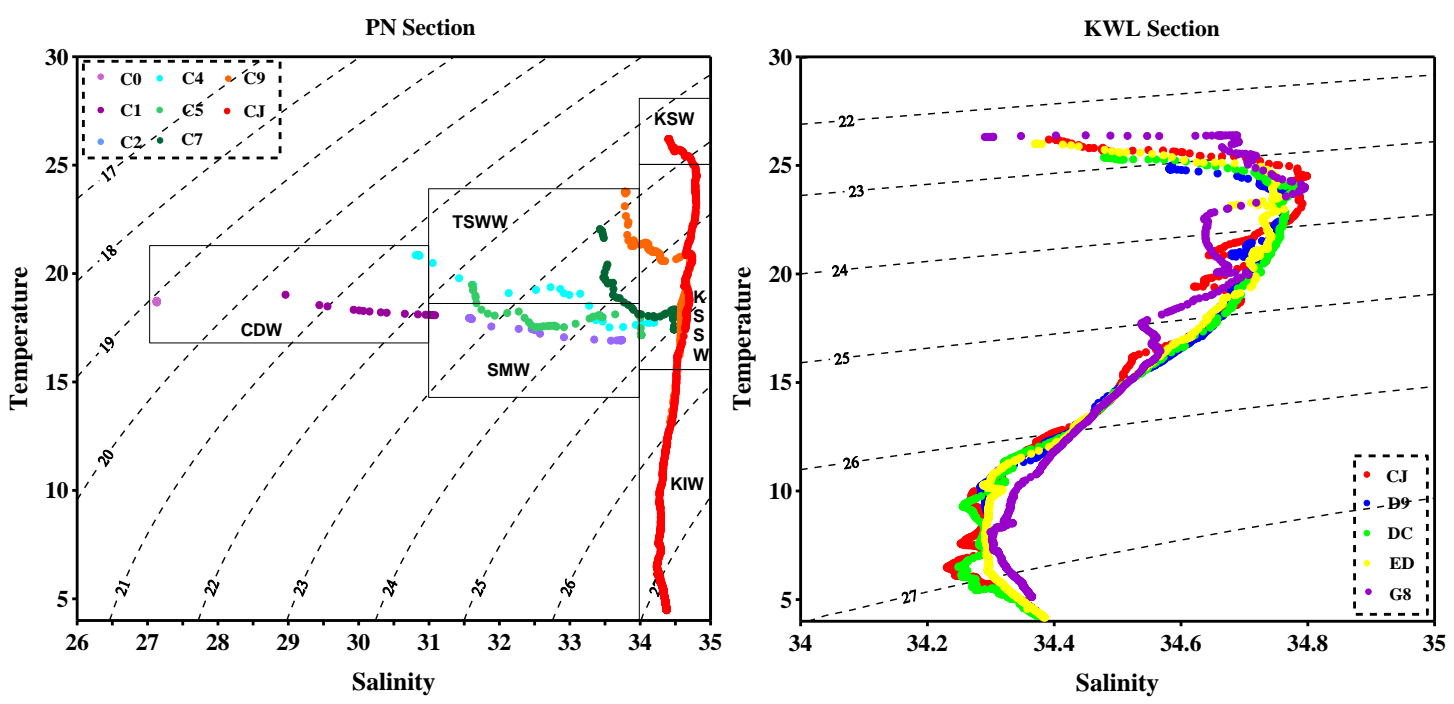

2 Fig. 3

3

4 

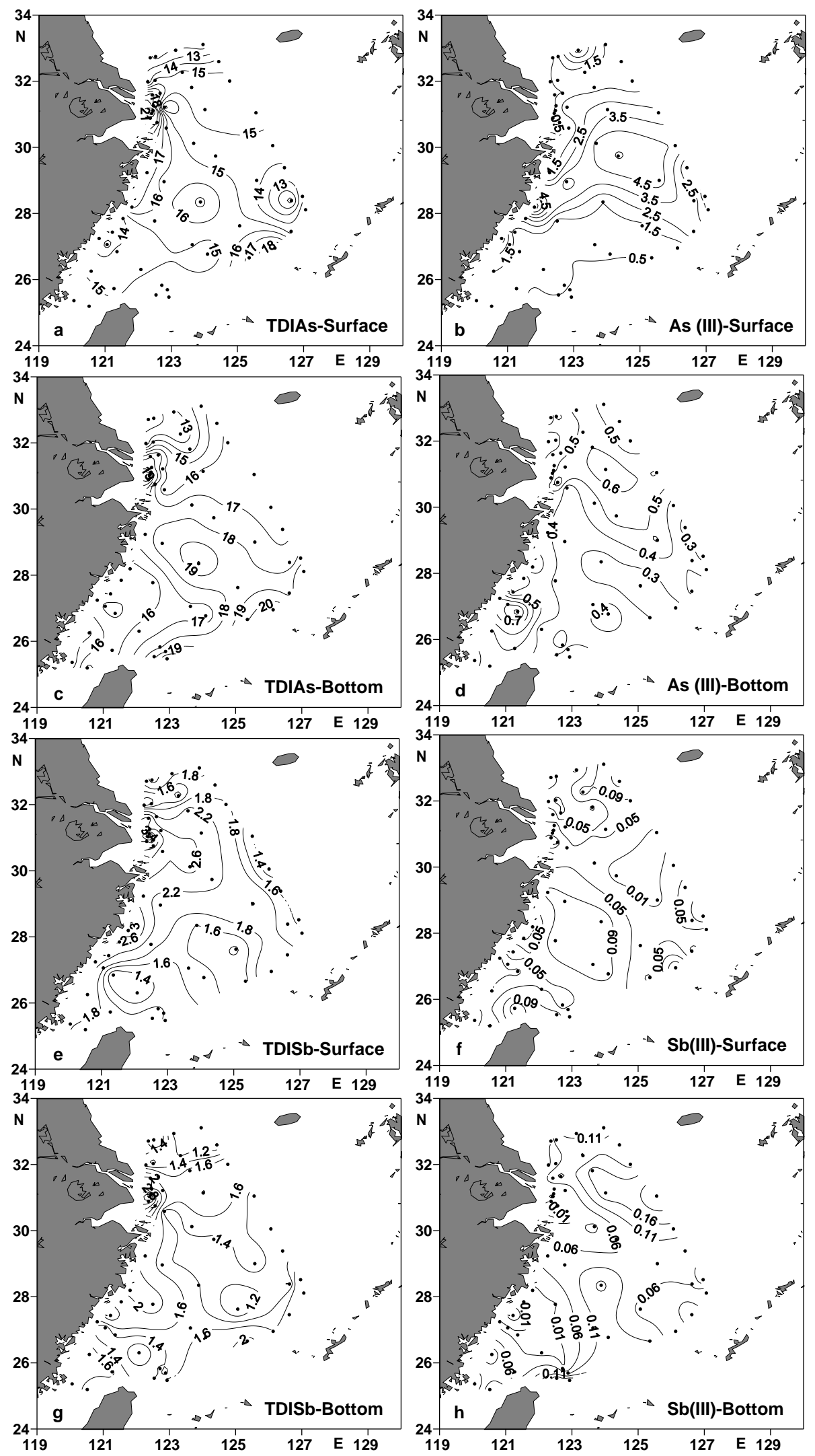

Fig. 4 

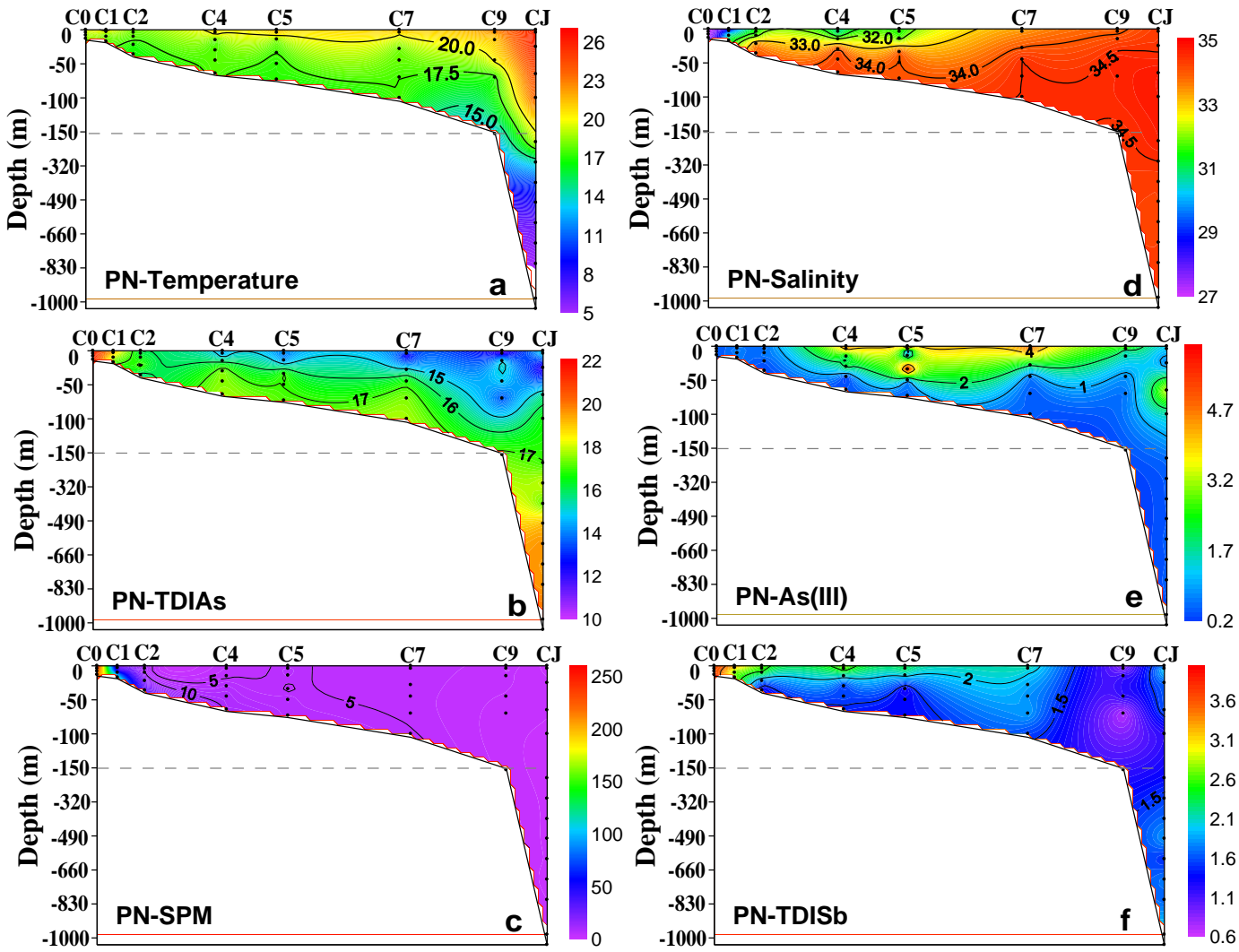

$3 \quad$ Fig. 5

4 

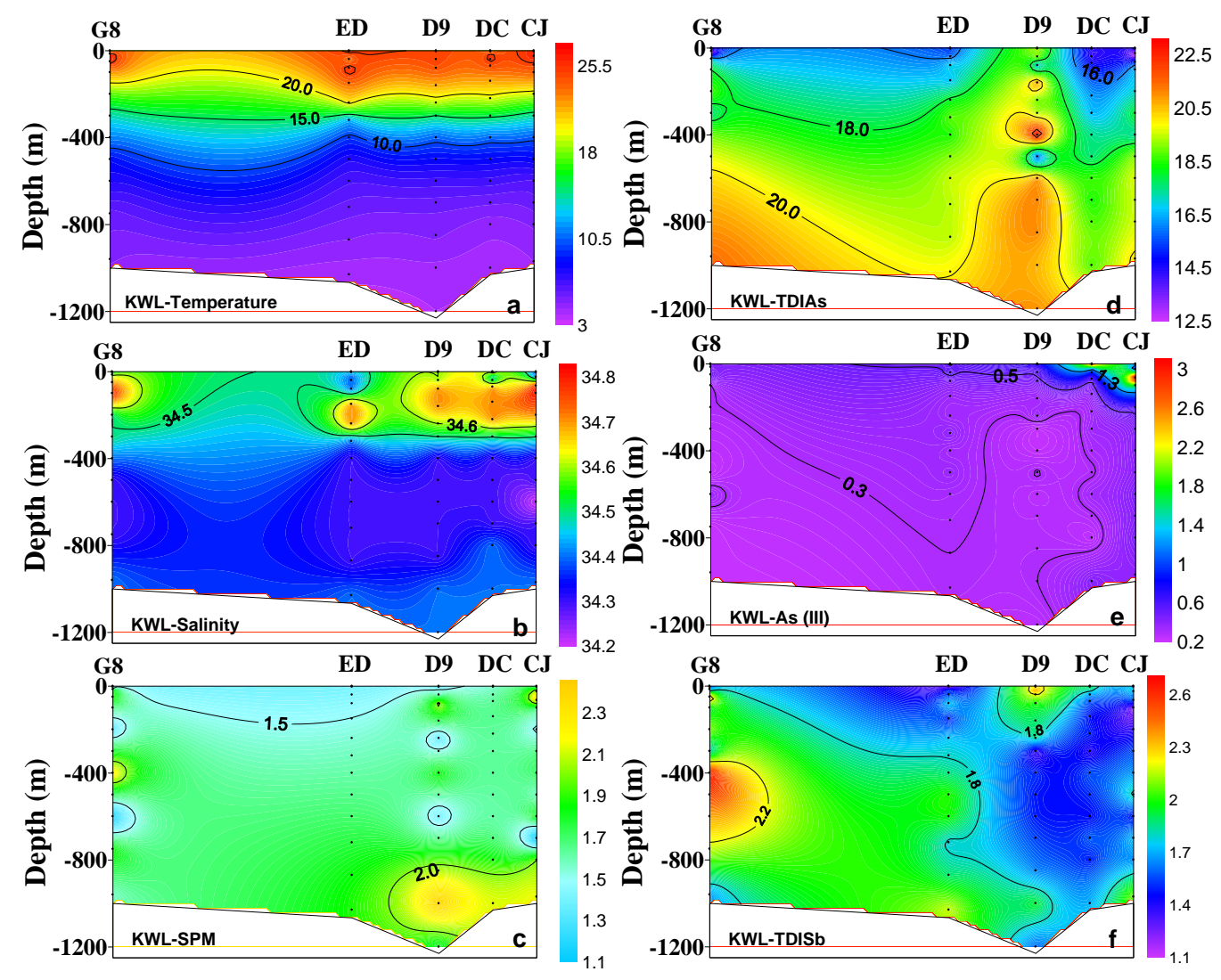

$3 \quad$ Fig. 6

4 
C4

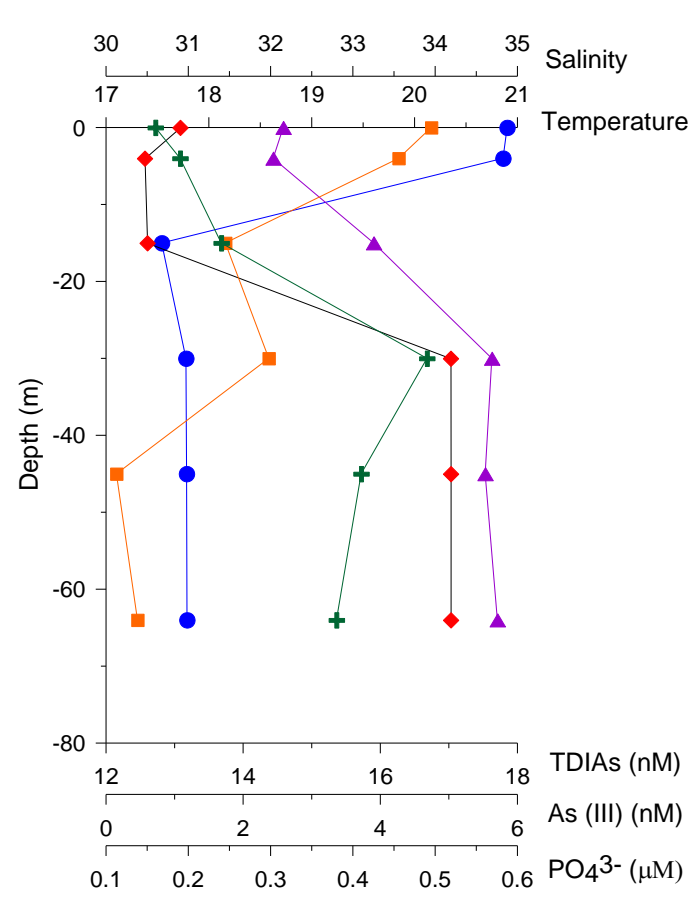

C7

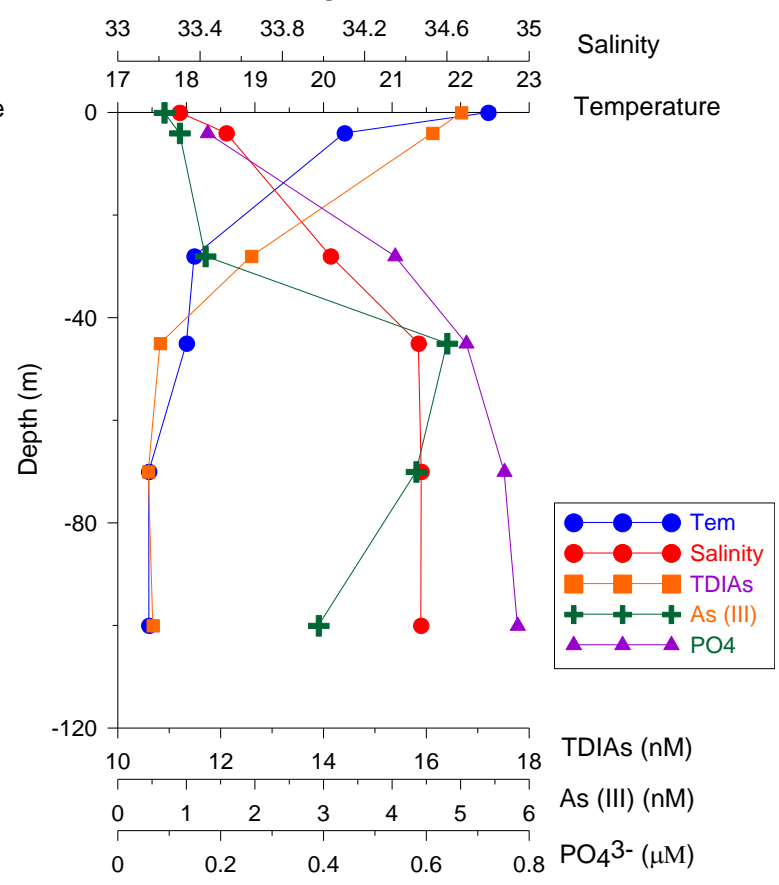

3 Fig. 7

4 


\section{East China Sea}

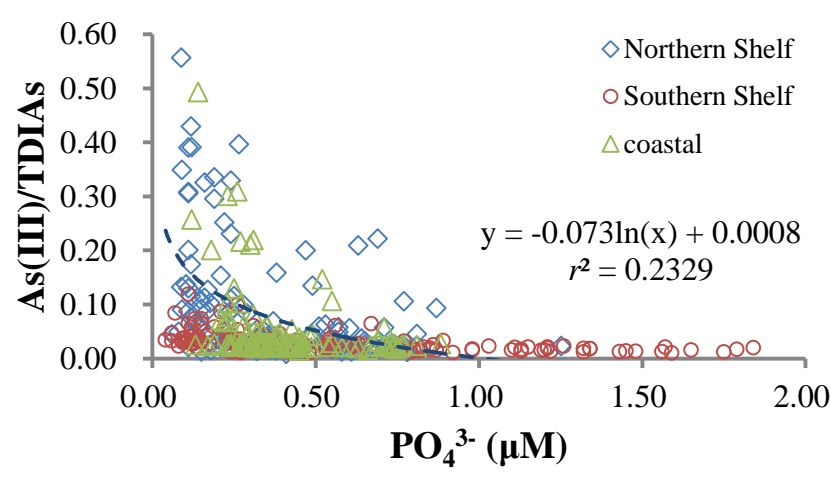

2 Fig. 8 
TDISb (nM)

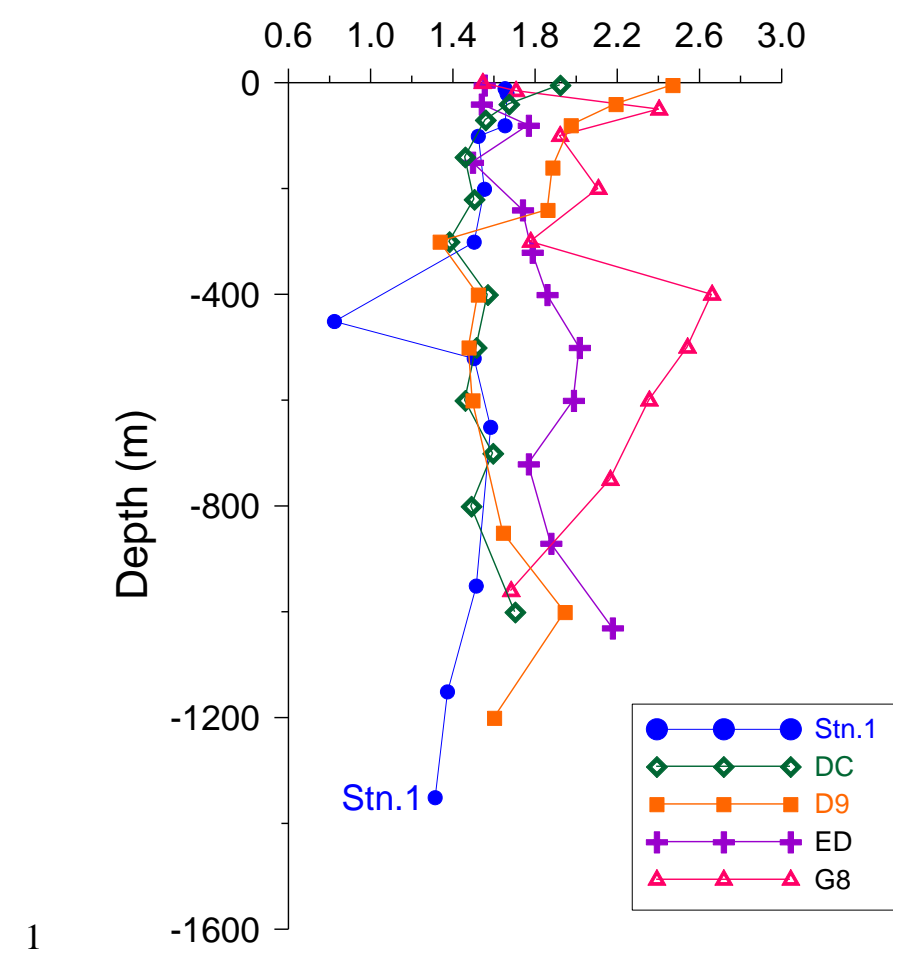

2 Fig. 9

3

4 
$1 \quad$ Table 1

2 The ranges and average (in bracket) concentrations of temperature, salinity, SPM, TDIAs, arsenite,

$3 \mathrm{TDISb}$ and $\mathrm{Sb}$ (III) and the ratios of $\mathrm{As}(\mathrm{III}) / \mathrm{TDIAs}$ and $\mathrm{Sb}(\mathrm{III}) / \mathrm{TDISb}$ in the surface and bottom layer of

4 the East China Sea covered by the cruise of spring 2011

\begin{tabular}{lllllllllll}
\hline Laye & Tempera & Salinity & SPM & TDIAs & As(III) & As(III)/T & TDISb & Sb (III) & Sb(III)/T \\
r & ture & & $(\mathrm{mg} / \mathrm{l})$ & $(\mathrm{nM})$ & $(\mathrm{nM})$ & $\mathrm{DIAs}$ & $(\mathrm{nM})$ & $(\mathrm{nM})$ & $\mathrm{DISb}$ \\
\hline Surfa & $14.83-26$ & $24.376-34$. & $1.2-252$. & $8.7-23$. & $0.33-8.5$ & $0.02-0.56$ & $1.16-4.9$ & BDL-0. & $0-0.10$ \\
$\mathrm{ce}$ & .33 & 585 & 3 & 9 & 2 & $(0.13 \pm 0.1$ & 8 & 18 & $(0.03 \pm 0.0$ \\
& $(20.2 \pm 3$. & $(32.210 \pm 2$. & $(14.9 \pm 36$ & $(15.3 \pm$ & $(1.83 \pm 1$ & $3)$ & $(2.13 \pm 0$ & $(0.05 \pm 0$ & $3)$ \\
& $47)$ & $290)$ & $.8)$ & $2.7)$ & $.82)$ & & $.82)$ & $.05)$ & \\
Bott & $4.00-23$. & $24.212-34$. & $1.6-856$. & $11.4-2$ & $0.19-1.9$ & $0.01-0.06$ & $0.84-4.7$ & BDL-0. & $0-0.21$ \\
om & 92 & 904 & 2 & 3.2 & 5 & $(0.03 \pm 0.0$ & 6 & 27 & $(0.05 \pm 0.0$ \\
& $(15.71 \pm 4$ & $(33.128 \pm 1$. & $(125.8 \pm 4$ & $(16.8 \pm$ & $(0.45 \pm 0$ & $1)$ & $(1.77 \pm 0$ & $(0.07 \pm 0$ & $5)$ \\
& $.62)$ & $985)$ & $6.3)$ & $2.5)$ & $.15)$ & & $.72)$ & $.07)$ & \\
\hline
\end{tabular}


Table 2

2 Comparison of the dissolved arsenic and antimony concentrations between ECS and world regions

\begin{tabular}{|c|c|c|c|c|c|}
\hline Region & TDIAs (nM) & As (III) (nM) & TDISb (nM) & $\mathrm{Sb}$ (III) (nM) & Reference \\
\hline ECS & $2.5-24.1(16.2)$ & $0.15-8.52(0.92)$ & $\begin{array}{l}0.71-4.98 \\
(1.84)\end{array}$ & $\begin{array}{l}\text { BDL-0.30 } \\
(0.08)\end{array}$ & this study \\
\hline m) & $\begin{array}{l}15.4-24.1 \\
(19.7)\end{array}$ & $0.22-0.44(0.32)$ & $\begin{array}{l}1.46-2.54 \\
(1.80)\end{array}$ & $\begin{array}{l}\text { BDL-0.27 } \\
(0.09)\end{array}$ & \\
\hline North Pacific & $\begin{array}{l}14.6 \pm 1.2 \\
\text { (surface) } \\
24.2 \pm 0.4 \text { (deep } \\
\text { water) }\end{array}$ & $\begin{array}{l}\text { BDL- } 0.7 \\
(0.10)(\text { deep } \\
\text { water) }\end{array}$ & $\begin{array}{l}1.16 \pm 0.35 \\
\text { (surface) } \\
0.83 \pm 0.08 \\
\text { (below } 2500 \mathrm{~m} \text { ) }\end{array}$ & BDL-1.0 & $\begin{array}{l}\text { Cutter and } \\
\text { Cutter, } 2006 \\
\text { Andreae, } 1979\end{array}$ \\
\hline $\begin{array}{l}\text { South Pacific } \\
\text { (surface) }\end{array}$ & $18 \pm 2$ & & & & $\begin{array}{l}\text { Ellwood and } \\
\text { Maher, } 2002\end{array}$ \\
\hline $\begin{array}{l}\text { Atlantic Ocean } \\
\text { (surface) }\end{array}$ & $16.3 \pm 2.1$ & 0.45 & $\begin{array}{l}1.25 \pm 1.44 \\
\text { (equatorial) }\end{array}$ & & $\begin{array}{l}\text { Cutter and } \\
\text { Cutter, 1998; } \\
\text { Middelburg et } \\
\text { al., } 1998 \\
\text { Cutter et al., } \\
2001\end{array}$ \\
\hline $\begin{array}{l}\text { Western Atlantic } \\
\text { (IOC) }\end{array}$ & & & & & $\begin{array}{l}\text { Cutter et al., } \\
2001\end{array}$ \\
\hline $\begin{array}{l}\text { Stn.10 } \\
\text { (southernmost) }\end{array}$ & & & & & \\
\hline Upper layer & & 0.35 & & & \\
\hline $\begin{array}{c}\text { NADW } \\
(2200-3200 \mathrm{~m})\end{array}$ & $21.2 \pm 1.7$ & $\begin{array}{l}0.09 \\
\text { (700m-bottom) }\end{array}$ & $0.91 \pm 0.12$ & & \\
\hline $\begin{array}{c}\text { AABW } \\
(3950-4460 \mathrm{~m})\end{array}$ & $20.4 \pm 0.4$ & & $0.53 \pm 0.05$ & & \\
\hline $\begin{array}{l}\text { Stn.8 (Brazil } \\
\text { Strait) }\end{array}$ & & & & & \\
\hline upper thermocline & & 0.37 & 1.46 & 0.02 & \\
\hline $\begin{array}{c}\text { AAIW (700-850 } \\
\text { m) }\end{array}$ & & 0.09 & 0.60 & $\mathrm{BDL}$ & \\
\hline $\begin{array}{c}\text { UCDW } \\
(900-1500 \mathrm{~m})\end{array}$ & & 0.10 & 0.68 & $\mathrm{BDL}$ & \\
\hline $\begin{array}{c}\text { NADW } \\
(1900-3300 \mathrm{~m})\end{array}$ & $19.4 \pm 0.3$ & & $0.72 \pm 0.15$ & BDL & \\
\hline $\begin{array}{c}\text { AABW } \\
(4700-5200 \mathrm{~m})\end{array}$ & $19.3 \pm 0.3$ & & $0.80 \pm 0.13$ & BDL & \\
\hline Stn.RF (Middle of & he deep & & & & \\
\hline Romanche Fracture & zone) & & & & \\
\hline 20-m mixed layer & & 0.29 & 2.2 & $\begin{array}{l}0.01 \text { (max. of } \\
\text { upper } 200 \mathrm{~m} \text { ) }\end{array}$ & \\
\hline
\end{tabular}




\begin{tabular}{|c|c|c|c|c|c|}
\hline $\begin{array}{c}\text { AAIW (600-800 } \\
\text { m) }\end{array}$ & $20.3 \pm 1.7$ & 0.06 (deep water) & $0.87 \pm 0.21$ & BDL & \\
\hline $\begin{array}{c}\text { NADW } \\
(1000-4000 \mathrm{~m})\end{array}$ & $19.6 \pm 1.6$ & & $1.07 \pm 0.27$ & BDL & \\
\hline $\begin{array}{c}\text { AABW } \\
(4800-5300 \mathrm{~m})\end{array}$ & $20.4 \pm 0.8$ & & $1.13 \pm 0.07$ & $\mathrm{BDL}$ & \\
\hline $\begin{array}{l}\text { Stn.6 } \\
\text { (northernmost) }\end{array}$ & & & & & \\
\hline surface & & 1.2 & 1.52 & & \\
\hline $\begin{array}{c}\text { AAIW (600-900 } \\
\text { m) }\end{array}$ & & 0.08 & 1.11 & BDL & \\
\hline $\begin{array}{c}\text { NADW } \\
(1700-4200 \mathrm{~m})\end{array}$ & $20.2 \pm 0.6$ & BDL & $1.07 \pm 0.07$ & BDL & \\
\hline $\begin{array}{c}\text { AABW } \\
(4500-4600 \mathrm{~m})\end{array}$ & $20.2 \pm 0.6$ & BDL & $1.27 \pm 0.01$ & BDL & \\
\hline Eastern Atlantic & & & & & Cutter and \\
\hline Ocean & & & & & Cutter, 1995 \\
\hline surface & $12.9 \pm 1.8$ & & $1.12 \pm 0.25$ & & \\
\hline $2000-4600 \mathrm{~m}$ & $19.1 \pm 0.7$ & & $1.08 \pm 0.13$ & & \\
\hline Southern Ocean & $\begin{array}{l}21.1-23.0 \\
(22.2 \pm 1.3 \\
\text { surface })\end{array}$ & 0.04 & & & $\begin{array}{l}\text { Featherstone et } \\
\text { al., 2001; }\end{array}$ \\
\hline & $\begin{array}{l}24.1 \pm 0.5 \\
\text { (below } 1000 \mathrm{~m} \text { ) }\end{array}$ & & & & $\begin{array}{l}\text { Santosa et al., } \\
1994\end{array}$ \\
\hline $\begin{array}{l}\text { Amazon River } \\
\text { plume }\end{array}$ & 9.83 & $0.7-1.9$ & $0.5-1.5$ & $0.03-0.06$ & $\begin{array}{l}\text { Cutter et al., } \\
2001\end{array}$ \\
\hline $\begin{array}{l}\text { Amazon River } \\
\left(3^{\circ} 13^{\prime} \mathrm{S}, 59^{\circ} 0.2^{\prime} \mathrm{W}\right)\end{array}$ & 2.8 & & 0.25 & & $\begin{array}{l}\text { Cutter et al., } \\
2001\end{array}$ \\
\hline
\end{tabular}

1 AABW: Antarctic Bottom Water; AAIW: Antarctic Intermediate Water; NADW: North Atlantic Deep

2 Water; UCDW: Upper Circumpolar Deep Water 
2 Budgets of dissolved antimony in the ECS

\begin{tabular}{|c|c|c|c|c|c|}
\hline Transport & Salinity $^{\mathrm{a}}$ & $\begin{array}{l}\text { Water fluxes }{ }^{\mathrm{a}} \\
(\mathrm{Sv})\end{array}$ & $\begin{array}{l}\mathrm{Sb} \\
(\mathrm{nM})\end{array}$ & $\begin{array}{l}\text { Sb flux } \\
\left(\mathrm{mol} \mathrm{s}^{-1}\right)\end{array}$ & Reference \\
\hline \multicolumn{6}{|l|}{ Input } \\
\hline Changjiang & 0 & $0.036-0.046$ & $10.1-12.6(11.4)$ & $0.36-0.58(0.48)^{\mathrm{b}}$ & This study \\
\hline \multicolumn{6}{|l|}{ Kuroshio water } \\
\hline KSW & $34.2-34.8$ & $0.84-0.94$ & $1.48-2.47(1.78)$ & $1.07-2.27(1.53)^{\mathrm{c}}$ & This study \\
\hline KSSW & & & $1.20-2.40(1.70)$ & & \\
\hline TSWW & $33.6-34.2$ & $1.88-3.16$ & $0.98-2.06(1.68)$ & $1.84-6.51(3.07)$ & This study \\
\hline \multicolumn{6}{|l|}{ Atmospheric } \\
\hline \multirow[t]{2}{*}{ dry } & \multicolumn{2}{|c|}{ dry deposition velocity $\left(\mathrm{cm} \mathrm{s}^{-1}\right)$} & $2.0 \pm 1.5$ & & Hsu et al., 2009 \\
\hline & \multicolumn{2}{|c|}{ aerosol $\mathrm{Sb}$ concentration $\left(\mathrm{ng} \mathrm{m}^{-3}\right)$} & $1.57 \pm 1.08$ (East China Sea) & $0.050 \pm 0.026^{\mathrm{d}}$ & Hsu et al., 2010 \\
\hline total & & & & $0.18 \pm 0.09^{\mathrm{e}}$ & \\
\hline \multicolumn{6}{|l|}{ Output } \\
\hline Yellow Sea & $31.15-32.75$ & 0.009 & $0.58-3.25(1.74)$ & $0.0052-0.029(0.016)$ & This study \\
\hline Shelf Mixed Water & $31.15-34.30$ & $2.77-4.16$ & $0.63-2.74(1.50)$ & $1.74-11.4(5.20)$ & This study \\
\hline
\end{tabular}

${ }^{a}$ The salinity and water fluxes of the water masses are cited from Zhang et al. (2007);

${ }^{\mathrm{b}}$ Nearly $85.9 \%$ of the discharge empties into the ECS Shelf (Liu et al., 2003);

$5 \quad{ }^{c}$ Assume that the incursion of the Kuroshio from north of Taiwan mainly compose by the KSW (i.e., 25\%) and the KSSW (i.e., 75\%);

6 Estimated according to the aerosol samples collected at different sites and average solubility of Sb in dry deposition is $36 \pm 7 \%$ (Hsu et al., 2010).

$7 \quad{ }^{\mathrm{e}}$ Estimated according to the average ratio between seasonal variations in atmospheric deposition through dry and wet deposition to northern Taiwan between 2002 and 82006 , with the result of $27 \%$ and $73 \%$, respectively. Assume that the solubilies of Sb in dry and wet deposition are same (Hsu et al., 2009). 